Article

\title{
Economic Assessment of Distributed Generation Technologies: A Feasibility Study and Comparison with the Literature
}

\author{
Ameena Saad Al-Sumaiti ${ }^{1, *}$, Abdollah Kavousi-Fard ${ }^{2}$, Magdy Salama ${ }^{3}$, \\ Motahareh Pourbehzadi ${ }^{4} \mathbb{D}$, Srikanth Reddy ${ }^{1}$ and Muhammad Babar Rasheed ${ }^{5}$ \\ 1 Advanced Power and Energy Center, Department of Electrical Engineering and Computer Science, \\ Khalifa University, P.O. Box 127788 Abu Dhabi, UAE; srikanth.konda@ku.ac.ae \\ 2 Department of Electronics and Electrical Engineering, University of Michigan, Ann Arbor, MI 48126, USA; \\ akavousi@umich.edu \\ 3 Department of Electrical and Computer Engineering, University of Waterloo, Waterloo, ON N2L 3G1, \\ Canada; msalama@uwaterloo.ca \\ 4 Department of Electrical Engineering, University of South Florida, Tampa, FL 33620, USA; \\ mpourbehzadi@usf.edu \\ 5 Department of Electronics and Electrical Systems, The University of Lahore, Lahore 54590, Pakistan; \\ muhammad.babar@es.uol.edu.pk \\ * Correspondence: ameena.alsumaiti@ku.ac.ae
}

Received: 10 March 2020; Accepted: 19 May 2020; Published: 1 June 2020

Abstract: With the negative climate impact of fossil fuel power generation and the requirement of global policy to shift towards a green mix of energy production, the investment in renewable energy is an opportunity in developing countries. However, poor economy associated with limited income, funds availability, and regulations governing project funding and development are key factors that challenge investors in the energy sector. Given the various power generation resources, including renewables, it is necessary to evaluate the possible power generation investment options from an economic perspective. To realize this objective, solar PV, wind and diesel power generations are economically compared, considering the incremental rate of return and incremental benefit to cost ratio techniques. The alternative investment options of distributed generation technologies are evaluated for Maharashtra, India under different depreciation methods, and the effect of the latter on selecting the best investment candidate is investigated. The paper also conducts sensitivity analysis to examine the impact of capital cost, operation and maintenance cost, and fuel cost variations on the selection decision considering a comparison of the different general projects' cash flow structures discussed in the literature. The economic aspects of selecting a project among possible alternatives for an investment in the power sector are analyzed, and the presented review provides comprehensive comparisons with respect to the literature approaches. The results reveal that, in the benchmark case study, the PV project is rejected and disregarded from further comparisons with other candidate projects since its equity internal rate of return $(10.25 \%)$ is less than the minimum accepted rate of return, leaving the selection between wind and diesel energy projects. The study reveals that the incremental rates of return under such a comparison are $37.88 \%, 45.94 \%$ and $37.50 \%$ when MACRS, declining balance and straight line depreciations techniques are applied, respectively. Thus, the wind energy project is the favored option in this case. For the economic assessment of other case studies, the application of both sensitivity analysis on the capital cost and operation and maintenance cost and literature approaches to structure the projects reveal that wind energy for Maharashtra, India is a more attractive and feasible option compared to other distribution generation projects, while diesel is only considered to be a good option when its fuel cost is reduced by $5 \%$. Finally, the paper highlights policy implications that can influence the decision to move towards investment in distributed generation technologies as a future research direction. 
Keywords: distributed generation technologies; modified accelerated cost recovery system; incremental rate of return analysis; benefit to cost ratio; depreciation methods; policy implications

\section{Introduction}

Despite the limited fossil fuel resources for power generation and the financial limitations in many developing countries that restrict building new power stations to support the electricity demand of the growing population, global policy is currently directed towards the adoption of green initiatives [1-3]. Although demand side management may serve as an option to manage the load [4-12], electricity demand growth remains a challenge compared to fossil fuel exploration. Thus, it is appealing for the global society to search for alternative environment-friendly resources for energy supply, i.e., renewable energy sources (RESs). Even though renewable energy projects exist in developing countries, as claimed by [13], only $10.4 \%$ of the energy consumption is from modern renewables [3]. High capital investment costs, limited income, and regulatory policies placed on project funding are the main underlying reasons limiting the exploitation of RESs. Such projects need to undergo a thoughtful management process [14-17]. RESs can be deployed in alternative ventures such as wind energy and solar energy-based projects [1,18-20]. Selecting the best candidate project for investment remains an issue, since such projects are governed by bank loans, investors' contributions, the regime's taxation systems, etc. [21,22]. This necessitates the demand for a pre-economic analysis of candidate projects for an investment in developing countries. On the other hand, some developing countries' utilities have concluded contracts over the short term to purchase electricity [1]. Diesel generators, which are lower in capital cost compared to renewables, might be an alternative option [23]. To address the aforementioned paradox, diesel generators, wind, and solar PV(photovoltaic) projects are to be economically evaluated considering their operational life, such that the best project can be recommended to local investors of limited funds.

The cash flows of some of these projects in India have been studied for different objectives such as determining an electricity tariff [24], individual projects' equity internal rate of return, and pay-back periods [25]. Meanwhile, the present paper targets the definition of long-term economically preferred investment given renewable and nonrenewable investment options, with a focus on Maharashtra, India. For wind energy-based projects, a complicated financing structure of wind exists [26], where the internal rate of return of wind energy projects is calculated based on the equity under a declining balance depreciation technique. The authors of [26] took the sensitivity and risk analysis of the project into consideration, as well. In more recent studies, the advantages of offshore wind generation against onshore wind generation have been highlighted through life cycle analysis (LCA), showing a $48 \%$ improvement in the sustainability of the project [27]. The studies on offshore wind have been further extended for floating wind farms with respect to their sensitivity in terms of the internal rate of return, the payback time, the cost of power and the levelized cost of energy (LCOE) [28]. On the other hand, with respect to the solar energy-based investment projects [29], an attempt is made to estimate the cost of PV projects considering different PV technologies, market trends, and future growth in the capacity of the installed PV. In [29], the module-selling price was considered relative to its performance. In [30], the operation and maintenance costs of PVs were evaluated for different sites, while placing an emphasis on the future projections of the operation and maintenance cost for any future installation. Furthermore, the techno-economic viability of PV in India was analyzed in [25] in order to determine the equity internal rate of return and to find the payback period of a $5 \mathrm{MW}$ PV system using the HOMER software and RETScreen software to perform the analysis and to collect the average solar radiation from both NASA SSE and the Meteorological Department in India. In another study, [31], the economic analysis of a rooftop PV plant was performed alongside design and simulation. Both the investment and maintenance costs, over the whole lifespan of a domestic $110 \mathrm{kWp}$ rooftop plant, were considered for the analysis. Moreover, an economic analysis of rooftop systems was summarized for 
various countries with respect to their feasibilities [32]. The economic impact of the PV system on grid operation was assessed in [33]. The economic analysis of systems involving PV power generation has been extended to include other sources of renewable energy generation, such as wind energy, and the economic analysis of hybrid renewable installations has been performed [34-36]. Most such studies have aimed at electrifying rural, standalone and off-grid areas such as islands. In terms of distributed generation technologies, the authors of [37] considered reviewing the different distributed generation technologies and evaluating the available options focusing on the future potential and the generation cost of the technologies considering the load factor and discount rate. Energy storage systems have also been identified and analyzed for distributed energy systems and hybrid energy systems $[38,39]$.

The rest of this paper is organized as follows: Section 2 summarizes the research gaps and the contribution of this work. Section 3 discusses the current scenario in India in terms of power generation and demand and highlights issues experienced by investors in the power sector. In Section 4 , the basic assumptions of funding a project are introduced. Section 5 covers the associated costs of a project. The governing factors that influence the cash flow structure are discussed in Section 6 . Section 7 introduces the incremental rate of return analysis. Section 8 covers sensitivity analysis and the decision-making concept. The incremental benefit to cost ratio used for sensitivity analysis on the diesel cost variation is discussed in Section 9. Economic analyses of different projects and a comparison based on the literature review are provided in Section 10. Section 11 highlights the policy implications associated with investments in distributed generation technologies. Finally, the concluding remarks are given in Section 12.

\section{Research Gaps and Contribution}

The research gaps in the reviewed literature have been identified and summarized as follows: The research work in [19] targeted minimizing the energy cost of a water-energy network to ensure that demand was met. Although this work considered the renewable energy integration in the form of $\mathrm{PV}$ and diesel generator as sources of power supply, it did not provide any clarification on the reason behind selecting these specific types of systems. Moreover, the costs accounted for in the study were limited to the 24-hourly nodal prices at the point of common coupling, rather than presenting the capital, operational and maintenance costs of such energy systems. In [20], the literature review targeted the optimal location and sizing of renewable energy systems in the grid. In the reviewed work, the cost of the system was accounted for in the form of locational marginal price, operating cost or installation and maintenance cost instead of providing a comparative study on what renewable energy would serve as a better choice over others. These studies were presented as grid planning studies instead of economic feasibility studies aiming towards an investment. Although an economic assessment of RESs was presented in [21], the study was focused on the regulations of a selected country, considered specific cash flow, and did not account for nonrenewable energy sources such as diesel, as will be shown in this paper. Moreover, the work in [21] neither investigated how different definitions of cash flow structure could influence the decision towards an investment, nor did it conduct a sensitivity analysis for studying the effect of variations in the capital, operation and maintenance costs on such a decision, as will be considered in this work. The study in [22] focused only on solar PV projects and presented a procedure for regulating funding requirements of such projects. This study did not address other types of RESs. Although the diesel generator cost is lower than the cost of renewable energy systems such as $\mathrm{PV}$ and wind turbines, the question is whether such investments in non-clean sources of energy will be favorable over the long term when accounting not only for the capital cost of the project, but also for the annual costs (e.g., fuel cost, operational and maintenance cost, etc.). Such investigations are carried out in this paper. The implementation of projects' cash flows in the literature/practice has been directed towards specific goals such as those highlighted earlier (electricity tariff [24], equity internal rate of return and pay-back periods [25]). In comparison to [24,25], the present paper is focused on identifying the most viable investment, from an economic perspective, among various power generation projects. The work in [26] applied a selected depreciation type to the project cash flow, estimated the internal rate 
of return under these considerations, and conducted a corresponding selectivity analysis. The impact of other types of depreciation on the internal rate of return analysis was not considered. Additionally, no comparative analysis was conducted with respect to other types of renewable energy systems, as will be performed in this work. The study in [27] was limited to four types of wind turbines (two onshore and two offshore), without considering other types of renewable energy systems, such as those considered in our study. Additionally, the sensitivity analysis conducted in [27] was focused on estimating the emissions/kWh with respect to the variation in the electricity generation and the lifetime of wind turbines. The life cycle assessment in [27] considered the production prices for every energy and material input used, with no investigation being conducted in order to study the impact of the variable costs in renewable energy systems (capital cost and operation and maintenance cost) on the decision to invest in renewable energy. The study in [28] was focused on one type of renewable energy system (floating offshore wind turbines at different sites) instead of having a comprehensive look at other sources of renewable energy systems. Additionally, the sensitivity analysis was conducted based on the levelized cost of the tariff, rather than applying the incremental rate of return analysis to select the best renewable energy investment. In [29], the work concentrated on one type of renewable energy (solar PV) and provided the cost of PV modules, the potential for cost reduction, and the levelized cost of solar PV electricity, rather than comparing this type of energy with other types of RESs in consideration of these aspects of costs. The work in [30] was also limited to one type of energy (solar PV), and the only type of cost studied was the operation and maintenance cost. There was no investigation into the effect of variations in project capital cost on the decision to invest. Although [31] looked at the installation cost of PV systems and indicated that such costs were beneficial considering the lifetime of the project, which can reach 25 years, the authors did not provide and visualize the cost estimation on a yearly basis. Thus, a more accurate economic analysis of such systems is needed. In [32], a better economic analysis was conducted in consideration of various economic parameters to assess the investment of PV systems in different countries around the world, such as the net present value, internal rate of return, simple and discounted payback periods, and profitability index. However, the work only considered one type of energy, and did not apply any incremental rate of return analysis as an approach to identify which project should be rejected among alternatives. Additionally, such parameters were considered to assess different sizes of PV investments in different countries, instead of simply assuming the same system rating in the same country, in order to analyze which location would serve as the best location for the installation of PV systems. The work in [33] was focused on analyzing the cost of grid losses minimized through the installation of PV systems, rather than simply looking at the price of PV investment for the chosen PV system ratings, and how this can be reflected in the prices of energy losses. In [35], economic pointers, including the net present cost, the cost of energy, and the primary capital cost of the project were chosen to identify resourceful configurations of $\mathrm{PV}$, wind and diesel for off-grid electrification in Columbia. Additionally, [36,38] considered similar pointers for a case study of the hybrid wind-diesel-battery-power convertor-electrolyzer system in Tehran, Iran and PV-diesel with flywheel storage for Makkah, KSA, respectively. Homer software was used in $[35,36,38,39]$ for system design and analysis purposes. In [37], the costs of generation from various power generation technologies were compared from the perspective of annualized life cycle cost as an approach, rather than deploying a concept whereby a project is accepted or rejected based on an incremental rate of return analysis. Although the cash flow structure was presented in [40], the feasibility study of cost integration into the cash flow structure is to be disregarded, as such a cost is well-known to be sunk, as per [41], and thus it should not be considered. It was indicated in [34] that the lack of understanding of projects' cash flows on the part financing institutions is one of the barriers to implementing renewable energy systems on islands.

The cash flow structure is subject to definitions of its main components. Such definitions have been regarded differently in practice. Therefore, this paper will look at these various definitions and will show how the implementation of such definitions affects the decision to invest in power generation, among the alternatives. The present paper will consider various aspects of assessing 
candidate investment options to choose the best project to devote attention to in terms of enabling access to green electricity in the selected region of Maharashtra, India. Projects' cash flows will follow the general budget structure of a project as discussed in [26,40], in consideration of the corrections to some of the concepts presented in [41], as in the case of the sunk cost. In this paper, the incremental rate of return analysis is applied as a technique for comparing projects' cash flows in order to choose an investment option among PV, wind and diesel generator projects. Such a treatment will account for the project's capital cost depreciated over its operation under a modified accelerated cost recovery system as a recent depreciation method compared to the straight line and declining balance depreciation methods presented in $[26,40,41]$. Furthermore, depreciation projects' salvage and project internal rate of return are factors governing projects' cash flows that are treated differently in the literature/practice. This paper will investigate the effect of such different treatments and definitions of these concepts on the choice of a project to invest in. When the decision cannot be determined based on the incremental rate of return analysis, the incremental benefit to cost ratio technique is applied as an alternative. Moreover, the effect of the variation of projects' major types of costs on the decision towards a selection of a project among possible options will be investigated thoroughly.

In summary, the economic aspects for choosing a project may be decisive in most cases of average projects (not in the case of demos or when well-known architects define and structure the project). Thus, sharing knowledge, definitions, methods, and the different treatments of project cash flow components contribute to a worldwide checklist and approaches. This is what this paper aims to contribute.

\section{The Current Indian Scenario}

The yearly gross electricity generation in India for the year 2018-2019 has been estimated to be 1,021,997 GWh from coal, $129 \mathrm{GWh}$ from oil, and 49,886 GWh from gas [42]. According to the data in [43], the estimated contribution of such resources represented $78.16 \%$ of the total gross electricity generation from both renewable and nonrenewable power generation. The yearly gross of electricity generation from renewables (wind, hydro, solar, biomass, etc.) was far below that, at almost $9.24 \%$, while nuclear and pumped storage gross electricity generation represented $12.59 \%$ of the total gross electricity generation in India [42]. The electricity demand of the domestic sector in 2018-2019 was 296,219 GWh, while the commercial, industrial, traction, and agricultural sectors accounted for 98,622 GWh, 492,361 GWh, 18,188 GWh, 211,609 GWh, respectively, and miscellaneous activities accounted for 79,309 GWh [44]. As of the October 2019 executive summary on the power sector by the Central Electricity Authority in India, a 0.5\% shortage of power had been experienced [42].

Maharashtra, a state in India located in the western peninsular region, required 23,621 MW at peak demand for the period of April 2019-October 2019; however, the peak demand supplies corresponded to $23,613 \mathrm{MW}$, indicating a deficiency of $8 \mathrm{MW}$. In addition to that, the three-phase supply was of $9 \mathrm{~h} /$ day [42]. In 2019, the peak power demand of Maharashtra exhibited an increase by more than 3\% in comparison to the previous fiscal year. For this period, the nation's gross electricity consumption was almost $1200 \mathrm{kWh}$ per capita [45].

India is ranked third in greenhouse gas emissions worldwide. According to [46], of the $1337 \mathrm{TWh}$ energy produced, $916 \mathrm{TWh}$ was recognized to be from fossil fuels. Although [47] indicates that the future energy demand is anticipated to increase as a result of climate change, and [48] attributes a fifth of the worldwide growth in energy demand to weather conditions, reference [49] recognizes the main driver of heating and cooling demand to be energy policy, rather than the climate. The International Energy Agency estimates a massive demand for fossil fuel energy, unless a change in direction can be found. According to the International Energy Agency, fuel demand has increased. The contribution of fossil fuels represents $70 \%$ of this growing demand [48]. Although renewable energy projects exist, their growth is slow and cannot keep up with the growth in electricity demand [48]. The growth in energy demand is driven by the global economy, which exhibited a growth rate of 3.7\% in 2018 [48]. The growth in electricity demand worldwide grew to more than 23,000 TWh in 2018. India's energy 
demand showed a growth of more than 35 Mtoe, led by coal used for power production and oil use for transport [48].

The World Energy Outlook 2019 clarifies the effect of current decisions on energy systems in the future. If no policy actions are taken, then the current trend of energy demand is anticipated to increase by $1.30 \%$ per year until 2040, leading to an increase in emissions [50]. China and India contribute half of $1 \%$ growth in global energy demand [51]. Electricity consumption has been increasing dramatically, partly because India has extended its power grid and improved its reliability, and partly because economic conditions have improved. The World Energy Outlook 2019 designated a pathway to enable a variety of milestones such as climate, energy access, etc., while ensuring access to reliable and affordable energy for the growing population [50].

The per capita energy consumption in India was 23,355 MJ in 2017-2018, and this exhibited a growth rate of $3.87 \%$ in comparison to the previous year [52]. Still, this energy demand per capita remained well below that of the developed world, suggesting that a much greater demand for electric power may emerge.

Therefore, India has to focus on the installation of renewable energy systems to achieve a goal of $17 \%$ more renewable power capacity by 2030 [53]. The provisional renewable energy generation in India includes wind, solar, biomass, bagasse, small hydro, and others [54]. India is targeting the installation of $175 \mathrm{GW}$ of clean energy by March 2020 [53]. The Indian renewable energy targets and policies indicate that the renewable targets of this country are in the fields of power, heating/cooling and transport [55]. According to [55], the Indian government has an existing policy covering feed and tender frameworks for almost all of the policies and incentives illustrated in Figure 1. However, there are some doubts that the country will be able to attain the renewable energy milestones, as a result of financial strain, tariff caps, land acquisition, import duty on renewable energy systems, delays in payments to be made by electric utilities, and liquidity crises due to problems associated with the banking sector, according to [53]. Some companies have noticed increasing interest rates over the long lifecycles of their renewable energy projects. Concerns have been raised by investors and independent power producers about the renewable energy sector environment [53]. Therefore, finding sustainable and economical ways forward for energy production is especially important in India. Regulations in the Indian power sector are subject to change, and any assessment of renewable energy investments under them [21] may change with time, even though some aspects, such as tariffs, are set for long periods, as discussed in [22]. Therefore, in this paper, the target is a more general economic assessment of such projects with respect to the various definitions of parameters and terms shaping the cash flow structure of the projects.

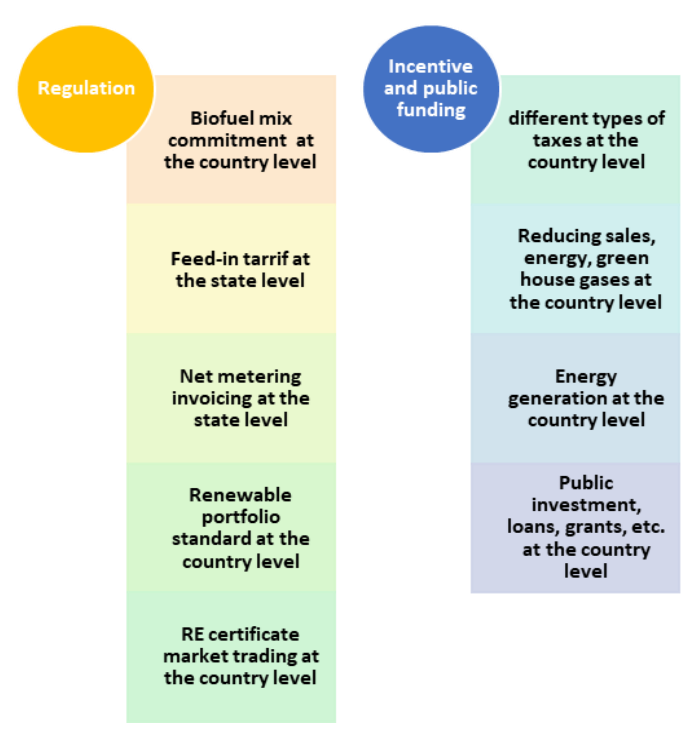

Figure 1. Indian policies and incentives. 


\section{Basic Assumptions in Funding a Project}

In this section, the basic assumptions in funding three different project scenarios are introduced. A $1 \mathrm{MW}$ wind project (WT), $1 \mathrm{MW}$ solar PV project (PV) and $1 \mathrm{MW}$ diesel generator project (DG) are considered to be under evaluation in selecting the most economically viable project in which to invest in Maharashtra, India. Such ratings do not necessarily belong to one system (e.g., one wind turbine) but can be the result of an aggregation of subsystems. If a project is selected for investment, then it is to be funded by two resources. These are bank loans and promoters' contributions. Bank loans reflect the debt component of the project cost, and represent $75 \%$ of the capital cost of the project. On the other hand, promoters are to cover $25 \%$ of this cost. The main assumption is that the debt is to be repaid within 7 years of the commencement of commercial operation of the project at an interest rate of $14 \%$. Such values regulating project funding are based on the economically evaluated $20 \mathrm{MW}$ wind project in India, according to [26], assuming that the rules apply for all three projects. Cash flow data are set mainly based on the selected Indian region for the case study.

\section{Project Associated Costs}

A project is composed of two types of costs, as shown in Figure 2. These are the capital cost of the project and the annual costs. The capital cost of the considered $1 \mathrm{MW}$ projects can be decomposed into the costs illustrated in Figure $2[23,29]$. The feasibility study costs described in $[26,40]$ as a component of the project capital cost, whose equity was considered in $[26,40]$ in order to find an equity internal rate of return of an individual project, is neglected in this paper. The main reason for disregarding it is that this cost is well known in economics to be a sunk cost, as defined by [41], and is not to be considered as a part of the capital cost of the project, since it takes place prior to the commercial operation of the project. Table 1 presents the capital cost of different types of power generation systems and their main subcomponents. The costs associated with the $1 \mathrm{MW}$ wind project are obtained as a percentage of the $20 \mathrm{MW}$ wind plant in [26]; meanwhile, the costs associated with the $1 \mathrm{MW}$ solar PV project are determined as a percentage of the costs of the $3 \mathrm{MW}$ PV plant in [56], and the installation cost is as defined in [23]. Other data on the capital cost in Table 1 are from/derived based on [23,26,37,56,57]. The second type of cost associated with projects is their annual cost. This type of cost is represented by the fuel cost, if any, and the non-fuel operation and maintenance cost. The latter can be decomposed into different segments [58,59]. Since the operation accounts for both constructors and operators [59], its cost should account for these types of costs. Maintenance cost accounts for costs of human resources including skilled personnel, plant operation and maintenance costs [58,59], costs of spare parts, costs of resource management, costs of ensuring equipment uptime, and costs of productive maintenance and reliability-centered maintenance [59]. 


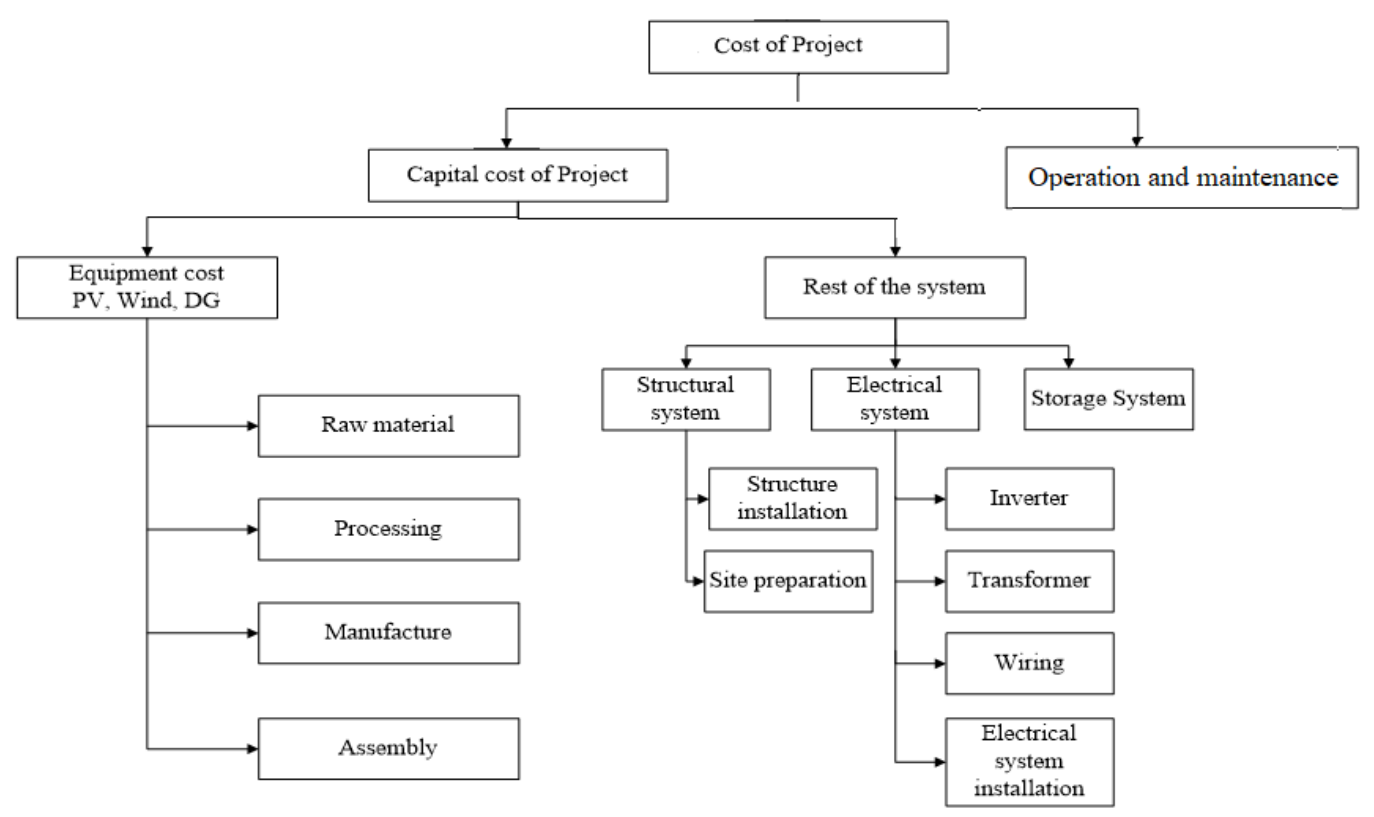

Figure 2. Cost of the project (capital cost components and operation and maintenance cost).

Table 1. Capital and annual cost decomposition of various $1 \mathrm{MW}$ electricity generation projects.

\begin{tabular}{lccccc}
\hline \multicolumn{7}{c}{ Capital cost decomposition of various 1 MW } \\
projects
\end{tabular}

Table 1 also shows the annual costs of the diesel generator, wind and solar PV projects. It is necessary to emphasize that the annual costs associated with the $1 \mathrm{MW}$ wind project were obtained as a percentage of the $20 \mathrm{MW}$ wind plant in [26], and the fuel cost of the diesel generator was determined at a full load for a year. Data on the annual costs of electricity generation projects in Table 1 are from/derived based on $[23,26,37,60,61]$.

\section{Factors Governing Cash Flow}

There are major factors governing projects' cash flows. These factors can have a significant impact on the incremental internal rate of return analysis for the selection of the best investment project when limited funding opportunities are available and there is a necessity to search for alternative sources of power supply when the current power generation resources are deficient with respect to electricity demand growth. Such factors include debt repayment and project depreciation. 


\subsection{Dept Repayment}

The amount of debt can be determined using Equation (1) [41], where ' $A$ ' is the repayment to be made on an annual basis, 'debt' is the percentage of the capital cost representing the loan, ' $\bar{i}^{\prime}$ reflects the debt's interest rate, ' $n$ ' corresponds to the period in years for the debt repayment, and ' $\bar{C}$ ' represents the funded project capital cost. The repayments are not necessarily equivalent every year. This concept also applies for the interest payments. Interest per year can be determined, following the approach discussed in [21], accounting for the annual debt interest rate, debt term, debt amount and the year number in which the annual repayment has to be made. Moreover, the payment without interest for each year can be determined by subtracting the interest from ' $A$ ' [40]. Figure 3 shows the debt repayment considering the interest, while Table 2 shows the annual bank repayments for the three projects under study in Indian Rupees (INR). 1 INR is almost \$0.014 USD.

$$
A=-\bar{C} * \operatorname{debt} * \frac{\bar{i} *(1+\bar{i})^{n}}{-1+(1+\bar{i})^{n}}
$$

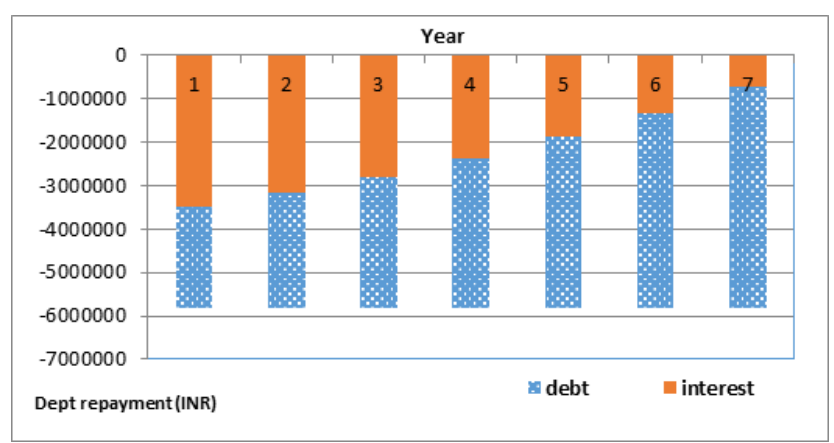

(a)

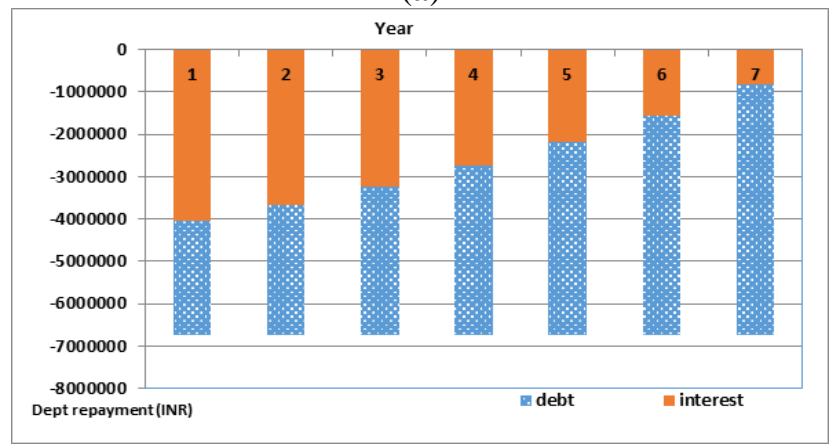

(b)

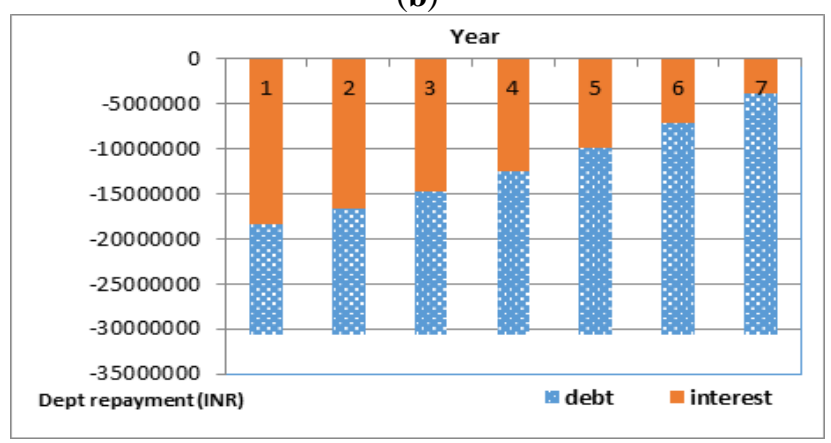

(c)

Figure 3. Debt repayment for (a) diesel generator project; (b) wind energy project; and (c) solar PV project. 
Table 2. Annual repayment.

\begin{tabular}{cccc}
\hline INR/Year & Diesel Generator & Wind Turbine & PV \\
\hline $\mathrm{A}$ & $-5,831,029.645$ & $-6,752,360.014$ & $-30,630,948$ \\
\hline
\end{tabular}

\subsection{Project Depreciation}

Project depreciation can be determined using straight line or declining balance techniques, which were common methods before 1981 [40,41]. Additionally, it can be estimated by the modified accelerated cost recovery system (MACRS), which has been demonstrated to cover the deficiencies of the aforementioned techniques, as discussed in [41]. The MACRS method is considered for evaluating the incremental internal rate of return when comparing the three projects. The simulation results of all three methods are presented in the following sections. It is important to emphasize that the project's depreciation is a part of the tax code that permits the business to account for the capital expenditure over time by deducting it. The methods presented in [40,41] and applied in [26] need estimations of the "useful life of the project", as well as the "salvage values". Even though investors can use such methods as a part of the project cash flow construction, there is a deficiency in the uniformity of reporting the depreciation expenses according to [41]. On the other hand, the MACRS method is selected in this paper, since it is a recent depreciation method and can overcome the deficiencies in the other methods, as further discussed in [41].

The considered projects have a 25-year life span and can be classified in the 20-year property class under the general depreciation system when applying MACRS. The depreciation is to be recovered in 21 years, with the depreciation rate available in $[41,62]$. The depreciation amount per year is given by Equation (2) [41], where ' $\omega$ ' is the depreciation amount in a year, 'MACRS' is MACRS rate as in [41,62], and ' $d$ ' is a depreciation tax basis (90\% [26]). Figure 4 shows the MACRS depreciation of the diesel generator project.

$$
\bar{\omega}=M A C R S * d * \bar{C}
$$

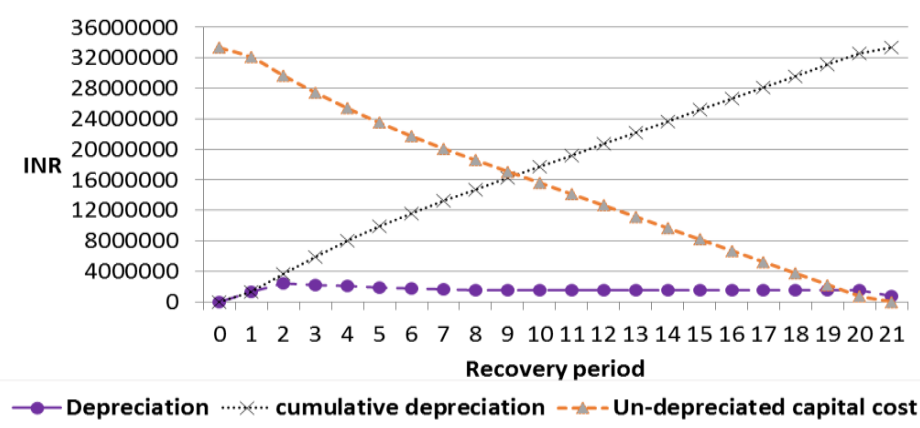

Figure 4. MACRS depreciation of diesel generator project.

\subsection{Cash Flow for Incremental Analysis}

For the application of the incremental rate of return method, the variation in the cash flow among alternative projects is to be determined according to Equation (3) [41], given that ' $D F(n)$ ' represents the difference between projects' after-tax cash flows given year number ' $n$ '. Moreover, ' $s$ ' and ' $u$ ' are project indices describing the type of the project, and 'Cash' symbolizes the after-tax cash flow of the project. It is important to emphasize that project ' $s$ ' is higher in cost when being compared to project ' $u$ '.

$$
D F(n)=\operatorname{Cash}_{s}(n)-\operatorname{Cash}_{u}(n)
$$


'Cash' can be estimated using Equation (4), where 'Bcash' is the cash flow before tax. ' $T$ ' is the amount of taxes to be paid when taxing the net income:

$$
\operatorname{Cash}(n)=B \operatorname{cash}(n)-T(n)
$$

The after-tax cash flow of individual projects is to be estimated using the after-tax values on the pretax cash flows that can be determined by applying Equations (5)-(8) [40,41,63], where 'Bcash $(\mathrm{n})^{\prime}$ denotes a project cash flow of year ' $\mathrm{n}$ ' prior to taxation, ' $I n(n)$ ' corresponds to the project cash income for year ' $n$ ', and ' $O(n)$ ' represents the cash payments of a project at year ' $n$ '. It is important to emphasize that the cash payment $(\mathrm{Out})$ in Equation (5) has a negative sign, as will be shown in Equation (8). The cash income of individual projects before taxation can be determined as in Equations (6) and (7), where ' $K$ ' is the electricity price from a generation source (INR/kWh), 'CUF' is the capacity use factor of a renewable power generation system, ' $t$ ' is 8760 hours/year, ' $R A T$ ' is a power generation source rating $(1 \mathrm{MW})$, 'esc' is the escalation rate (5\%) [26], ' $S P^{\prime}$ is the INR/kWh selling price of electricity generated from diesel generator (DG), ' $G$ ' is the $\mathrm{kWh}$ generated electricity from the diesel generator, and 'escg' is the escalation rate of the price of electricity generated from diesel $(5 \%)$.

$$
\begin{gathered}
\operatorname{Bcash}(n)=\operatorname{In}(n)+\operatorname{Out}(n) \\
\operatorname{In}(n)_{P v, \text { wind }}=K * C U F * t * R A T *(1+e s c)^{n} \\
\operatorname{In}(n)_{D G}=S P * G(n) *(1+e s c g)^{n}
\end{gathered}
$$

The electricity tariff is a fixed rate and is defined for the long term (years) for renewable energy in India. The electricity tariff differs from one project type to another. It is INR4.88/kWh for wind turbine energy; while the tariff is INR7.68/kWh for PV energy as referred to in [23], and it is INR13/kWh when considering a diesel generator [64].

The efficiency of the diesel generator is considered to be $40 \%$ [37]. The capacity use factor of a wind energy project is $20 \%$ [65], while it is $19 \%$ for PV [66,67]. The main reason behind using the capacity use factor to estimate the energy production is that this approach is recognized for its simplicity, as it considers the overall performance of the system over a year, and the capacity factor is calculated from many years' historical data. Using it does not obviate the data collection effort. Technology advances made it easy to track power production $[68,69]$. The capacity factor varies across regions and is subject to technologies. In this paper, the capacity use factor is selected based on "Maharashtra Electricity Regulatory Commission" in Mumbai for Maharashtra and assuming comparable renewable energy technologies. Regulatory entities governing projects have already defined the capacity use factor for sites. Maharashtra is divided into four wind zones. In this study, we deal with the capacity use factor of Zone 1. Given the size of the region over which the project is to be implemented, the use of capacity use factor is justified.

In terms of the emission-free credit, it is disregarded from the analysis, as trading such credits is subject to the approval of the renewable energy project of the National Clean Development Mechanism Authority in India. Foreign institutions in India are not permitted to participate in carbon trading directly, and this prohibition limits the trading [70]. Additionally, many developing countries do not apply this concept.

The cash payments for individual projects before taxation 'Out' can be determined as per Equation (8), where ' $O M$ ' is the operation and maintenance cost and its contingencies is ' $C O M^{\prime}$. ' $i n f$ ' is an inflation rate (2.5\%) [26], and 'fuel' represents the cost of fuel, if used, as in the case of diesel (INR16/L) [34].

$$
\operatorname{Out}(n)=\left\{\begin{array}{c}
-\bar{C} \forall n=0 \\
-\left((O M+C O M) *(1+\text { inf })^{\mathrm{n}}+\text { fuel } *(1+\text { esc })^{\mathrm{n}}\right) \forall n>0
\end{array}\right.
$$


The net income ' $\eta$ ' is taxable as given by Equations (9) and (10), where ' $T$ ' is the amount of tax, and ' $\lambda$ ' is the effective tax rate (35\% [26]). Figure 5 presents the net income to undergo taxation for different investment options under the application of MACRS depreciation to individual projects' cash flows.

$$
\begin{gathered}
T(n)=\lambda * \eta(n) \forall n>0 \\
\eta(n)=B \operatorname{cash}(n)-M A C R-\operatorname{interest}(n)
\end{gathered}
$$

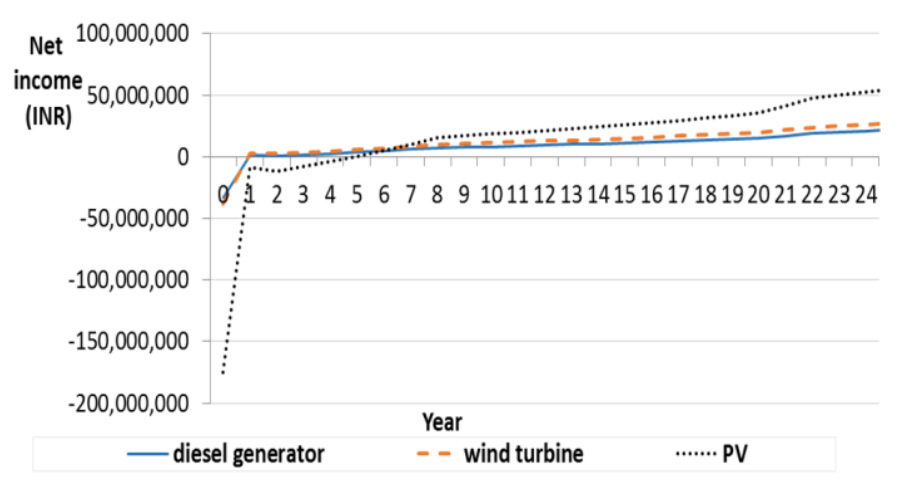

Figure 5. Net income of individual projects to undergo taxation.

\section{Incremental Rate of Return Analysis}

The incremental rate of return method [41] is employed to select the best economic project among wind, PV and diesel generator projects. Figure 6 describes the procedure of the incremental rate of return analysis, and the minimum accepted rate of return (MARR) is determined to be $14 \%$.

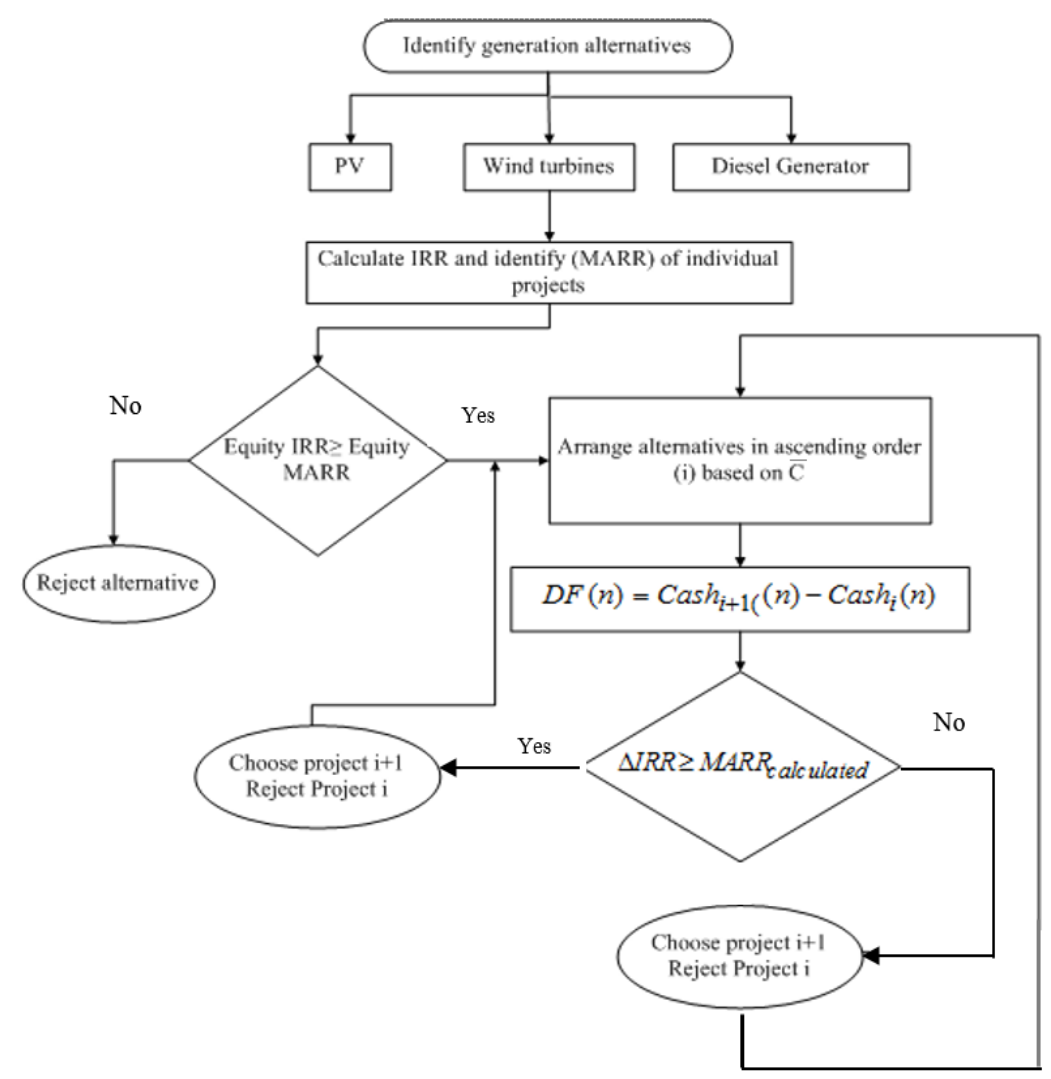

Figure 6. Incremental IRR analysis execution. 
Table 3 shows the equity IRR and the project IRR values of $1 \mathrm{MW}$ individual projects, while the capital cost at year zero and the effects of MACRS, straight line and declining balance depreciations on the after-tax cash flow are taken into consideration. The equity IRRs for the alternative projects are calculated considering the promoters' contribution to be the cost at year zero. As can be seen in Table 3 (equity IRR (\%) category), the PV project is rejected, as the calculated equity IRR is $11.55 \%$, which is less than its equity MARR.

Table 3. Equity IRR and project IRR values of $1 \mathrm{MW}$ projects.

\begin{tabular}{|c|c|c|c|}
\hline \multicolumn{4}{|c|}{ Equity IRR (\%) } \\
\hline Depreciation & MACRS & Declining Balance & Straight Line \\
\hline $1 \mathrm{MW}$ WT & 27.39 & 32.02 & 26.43 \\
\hline $1 \mathrm{MW}$ PV & 10.25 & 10.57 & 9.98 \\
\hline $1 \mathrm{MW}$ DG & 22.27 & 24.64 & 21.50 \\
\hline Rejected project based on equity IRR & Reject PV & Reject PV & Reject PV \\
\hline \multicolumn{4}{|c|}{ Project IRR (\%) } \\
\hline Depreciation & MACRS & Declining Balance & Straight Line \\
\hline WT & 21.62 & 23.29 & 21.21 \\
\hline PV & 11.33 & 11.58 & 11.11 \\
\hline DG & 19.09 & 20.20 & 18.70 \\
\hline Ascending order based on capital cost & & 1) $\mathrm{DG}, 2) \mathrm{WT}$ & \\
\hline Incremental IRR & $(\mathrm{WT}, \mathrm{DG})=37.88 \%$ & $(\mathrm{WT}, \mathrm{DG})=45.94 \%$ & $(\mathrm{WT}, \mathrm{DG})=37.40 \%$ \\
\hline Decision & Choose wind & Choose wind & Choose wind \\
\hline
\end{tabular}

The incremental internal rate of return is $37.88 \%$ when comparing the wind project to the diesel generator project. Since this rate is greater than the minimum accepted rate of return of the project, the wind project with higher capital cost compared to the diesel generator (DG) project is selected as the best investment option among the three projects.

\section{Sensitivity Analysis and Decision Making}

The selection of the most economically viable project through the application of the incremental internal rate of return analysis can be affected by variations of any of the cash flow components, such as, for example, the capital cost, the operation and maintenance cost, the fuel cost as in case of the diesel generator, the debt to equity ratio, the interest rate, etc.

In this section, the optimum decision is determined on the best project option to be considered for an investment by following the approach described in Figure 6. The project capital cost and its operation and maintenance cost are allowed to vary, and an investigation was carried out to determine the incremental internal rate of return according to which the best project can be selected.

The capital cost, shown previously in Table 1, was allowed to vary such that it increased by a maximum of $20 \%$ or decreased by a minimum by $20 \%$. The variation was performed at increments of $2.5 \%$ and $5 \%$. Table 4 serves as a guide to interested investors on the best option for an investment among $\mathrm{PV}$, wind and diesel generator projects when considering such variations. It can be comprehended from this table that the corresponding variation in the project internal rate of return (when considering the project capital cost depreciated though MACRS) is in the range of $[9.56 \%, 13.74 \%]$ for PV, [18.86\%, $25.56 \%]$ for wind, and [16.69\%, 22.46\%] for diesel generators. According to the incremental internal rate of return analysis, the wind project was the most economically viable project when considering the variation in the capital cost between $-20 \%$ and $20 \%$ of the total cost of the project compared to PV and diesel generator projects. 
Table 4. $1 \mathrm{MW}$ capital cost variation effect on decision-making.

\begin{tabular}{|c|c|c|c|c|c|}
\hline Type & $\begin{array}{l}\text { Capital Cost } \\
\text { Variation }\end{array}$ & $\begin{array}{l}\text { Project } \\
\text { IRR }\end{array}$ & $\begin{array}{c}\text { Status and Private IRR. } \\
\text { Accept only if Equity IRR }> \\
\text { Equity MARR }\end{array}$ & Order & $\Delta$ IRR \& Decision \\
\hline PV & \multirow{4}{*}{$-20 \%$} & 13.74 & Accept: $13.62 \%$ & 3 & \multirow{4}{*}{$\begin{array}{c}\text { First step: } \\
\text { (WT:DG) }=45.74 \%>14 \% \\
\text { Second step: }(\mathrm{WT}, \mathrm{PV})=9.56 \%<14 \% \\
\text { Decision: Choose WT }\end{array}$} \\
\hline & & & & & \\
\hline WT & & 25.56 & Accept: $36.53 \%$ & 2 & \\
\hline DG & & 22.46 & Accept: $28.90 \%$ & 1 & \\
\hline PV & \multirow{4}{*}{$-15 \%$} & 13.05 & Accept, $12.64 \%$ & 3 & \multirow{4}{*}{$\begin{array}{c}\text { First step: (WT:DG) }=45.01 \%>14 \% \\
\text { Second step: } \\
\text { (WT,PV) }=9.02 \%<14 \% \\
\text { Decision: Choose WT }\end{array}$} \\
\hline & & & & & \\
\hline WT & & 24.42 & Accept, $33.70 \%$ & 2 & \\
\hline DG & & 21.03 & Accept, $26.88 \%$ & 1 & \\
\hline PV & \multirow{3}{*}{$-10 \%$} & 12.43 & Reject: $11.75 \%$ & - & \multirow{3}{*}{$\begin{array}{c}(\mathrm{WT}, \mathrm{DG})=41.39 \% \\
\text { Decision: Choose WT }\end{array}$} \\
\hline WT & & 23.40 & Accept: $31.29 \%$ & 2 & \\
\hline DG & & 20.61 & Accept: $25.13 \%$ & 1 & \\
\hline PV & \multirow{3}{*}{$-5 \%$} & 11.85 & Reject $10.96 \%$ & - & \multirow{3}{*}{$\begin{array}{c}(\mathrm{WT}, \mathrm{DG})=39.55 \%>14 \% \\
\text { Decision: Choose WT }\end{array}$} \\
\hline WT & & 22.47 & Accept: $29.20 \%$ & 2 & \\
\hline DG & & 19.82 & Accept: $23.61 \%$ & 1 & \\
\hline PV & \multirow{3}{*}{$-2.5 \%$} & 11.58 & Reject: $10.60 \%$ & - & \multirow{3}{*}{$\begin{array}{c}(\mathrm{WT}, \mathrm{DG})=38.69 \%>14 \% \\
\text { Decision: Choose WT }\end{array}$} \\
\hline WT & & 22.04 & Accept: $28.87 \%$ & 2 & \\
\hline DG & & 19.45 & Accept: $22.92 \%$ & 1 & \\
\hline PV & \multirow{3}{*}{$0 \%$} & 11.33 & Reject: $10.25 \%$ & - & \multirow{3}{*}{$\begin{array}{c}(\mathrm{WT}, \mathrm{DG})=37.88 \%>14 \% \\
\text { Decision: Choose WT }\end{array}$} \\
\hline WT & & 21.62 & Accept: $27.39 \%$ & 2 & \\
\hline DG & & 19.09 & Accept: $22.27 \%$ & 1 & \\
\hline PV & \multirow{3}{*}{$2.5 \%$} & 11.08 & Reject: 9.92\% & - & \multirow{3}{*}{$\begin{array}{c}(\mathrm{WT}, \mathrm{DG})=37.11 \%>14 \% \\
\text { Decision: Choose wind }\end{array}$} \\
\hline WT & & 21.23 & Accept: $26.57 \%$ & 2 & \\
\hline DG & & 18.75 & Accept: $21.65 \%$ & 1 & \\
\hline PV & \multirow{3}{*}{$5 \%$} & 10.84 & Reject: $9.60 \%$ & - & \multirow{3}{*}{$\begin{array}{c}(\mathrm{WT}, \mathrm{DG})=36.38 \%>14 \% \\
\text { Decision: Choose WT }\end{array}$} \\
\hline WT & & 20.85 & Accept: $25.80 \%$ & 2 & \\
\hline DG & & 18.42 & Accept: $21.07 \%$ & 1 & \\
\hline PV & \multirow{3}{*}{$10 \%$} & 10.38 & Reject: $9.01 \%$ & - & \multirow{3}{*}{$\begin{array}{c}\text { (WT,DG })=35.00 \%>14 \% \\
\text { Decision: Choose WT }\end{array}$} \\
\hline WT & & 20.14 & Accept: $24.39 \%$ & 2 & \\
\hline DG & & 17.81 & Accept: $19.91 \%$ & 1 & \\
\hline PV & \multirow{3}{*}{$15 \%$} & 9.96 & Reject: $8.46 \%$ & - & \multirow{3}{*}{$\begin{array}{c}(\mathrm{WT}, \mathrm{DG})=34.05 \%>14 \% \\
\text { Decision: Choose WT }\end{array}$} \\
\hline WT & & 19.48 & Accept: $23.13 \%$ & 2 & \\
\hline DG & & 17.20 & Accept: $18.99 \%$ & 1 & \\
\hline PV & \multirow{3}{*}{$20 \%$} & 9.56 & Reject: $7.96 \%$ & - & \multirow{3}{*}{$\begin{array}{c}(\mathrm{WT}, \mathrm{DG})=32.78 \%>14 \% \\
\text { Decision: Choose WT }\end{array}$} \\
\hline WT & & 18.87 & Accept: $22.00 \%$ & 2 & \\
\hline DG & & 16.69 & Accept: $18.15 \%$ & 1 & \\
\hline
\end{tabular}

Then again, when the total operation and maintenance cost was allowed to vary such that it was increased by a maximum of $20 \%$ or reduced by a maximum of $20 \%$ of the cost, the wind project was the only option that revealed its economics to be selected among the studied projects, as can be seen from Table 5. Figure 7 describes how the internal rate of return can vary corresponding to the variation of the operation and maintenance cost. Here, the internal rate of return was determined in consideration of the capital cost of the project, rather than equity, as well as considering MACRS depreciation rather than straight line and declining balance depreciation methods. 
Table 5. Operation and maintenance cost variation effect on decision-making.

\begin{tabular}{|c|c|c|c|c|c|}
\hline Type & $\begin{array}{l}\text { O\&M } \\
\text { Cost } \\
\text { Variation }\end{array}$ & $\begin{array}{l}\text { Project } \\
\text { IRR }\end{array}$ & $\begin{array}{l}\text { Status and Private IRR } \\
\text { Accept only if (Equity IRR }> \\
\text { Equity MARR) }\end{array}$ & Order & $\Delta I R R \&$ Decision \\
\hline PV & \multirow{3}{*}{$-20 \%$} & 11.43 & Reject: $10.38 \%$ & - & \multirow{3}{*}{$\begin{array}{l}(\mathrm{WT}, \mathrm{DG})=33.59 \%>14 \% \\
\text { Decision: Choose WT }\end{array}$} \\
\hline WT & & 21.88 & Accept: $27.96 \%$ & 2 & \\
\hline DG & & 20.07 & Accept: $31.62 \%$ & 1 & \\
\hline PV & \multirow{3}{*}{$-15 \%$} & 11.40 & Reject: $10.35 \%$ & - & \multirow{3}{*}{$\begin{array}{l}(\mathrm{WT}, \mathrm{DG})=34.67 \%>14 \% \\
\text { Decision: Choose WT }\end{array}$} \\
\hline WT & & 21.82 & Accept: $27.81 \%$ & 2 & \\
\hline DG & & 19.82 & Accept: $28.69 \%$ & 1 & \\
\hline PV & \multirow{3}{*}{$-10 \%$} & 11.38 & Reject: $10.32 \%$ & - & \multirow{3}{*}{$\begin{array}{l}(\mathrm{WT}, \mathrm{DG})=35.74 \%>14 \% \\
\text { Decision: Choose WT }\end{array}$} \\
\hline WT & & 21.75 & Accept: $27.67 \%$ & 2 & \\
\hline DG & & 19.58 & Accept: $26.22 \%$ & 1 & \\
\hline PV & \multirow{3}{*}{$-5 \%$} & 11.35 & Reject: $10.28 \%$ & - & \multirow{3}{*}{$\begin{array}{l}(\mathrm{WT}, \mathrm{DG})=36.81 \%>14 \% \\
\text { Decision: Choose WT }\end{array}$} \\
\hline WT & & 21.69 & Accept: $27.53 \%$ & 2 & \\
\hline DG & & 19.34 & Accept: $24.10 \%$ & 1 & \\
\hline PV & \multirow{3}{*}{$-2.5 \%$} & 11.34 & Reject: $10.27 \%$ & - & \multirow{3}{*}{$\begin{array}{l}(\mathrm{WT}, \mathrm{DG})=37.35 \%>14 \% \\
\text { Decision: Choose WT }\end{array}$} \\
\hline WT & & 21.66 & Accept: $27.46 \%$ & 2 & \\
\hline DG & & 19.21 & Accept: $23.15 \%$ & 1 & \\
\hline PV & \multirow{3}{*}{$0 \%$} & 11.33 & Reject: $10.25 \%$ & - & \multirow{3}{*}{$\begin{array}{l}(\mathrm{WT}, \mathrm{DG})=37.88 \%>14 \% \\
\text { Decision: Choose WT }\end{array}$} \\
\hline WT & & 21.62 & Accept: $27.39 \%$ & 2 & \\
\hline DG & & 19.09 & Accept: $22.27 \%$ & 1 & \\
\hline PV & \multirow{3}{*}{$2.5 \%$} & 11.31 & Reject: $10.23 \%$ & - & \multirow{3}{*}{$\begin{array}{l}(\mathrm{WT}, \mathrm{DG})=38.42 \%>14 \% \\
\text { Decision: Choose WT }\end{array}$} \\
\hline WT & & 21.59 & Accept: $27.32 \%$ & 2 & \\
\hline DG & & 18.97 & Accept: $21.43 \%$ & 1 & \\
\hline PV & \multirow{3}{*}{$5 \%$} & 11.30 & Reject: $10.22 \%$ & - & \multirow{3}{*}{$\begin{array}{l}(\mathrm{WT}, \mathrm{DG})=38.96 \%>14 \% \\
\text { Decision: Choose WT }\end{array}$} \\
\hline WT & & 21.56 & Accept: $27.25 \%$ & 2 & \\
\hline DG & & 18.85 & Accept: $20.65 \%$ & 1 & \\
\hline PV & \multirow{3}{*}{$10 \%$} & 11.27 & Reject: $10.18 \%$ & - & \multirow{3}{*}{$\begin{array}{l}(\mathrm{WT}, \mathrm{DG})=40.03 \%>14 \% \\
\text { Decision: Choose WT }\end{array}$} \\
\hline WT & & 21.50 & Accept: $27.11 \%$ & 2 & \\
\hline DG & & 18.60 & Accept: $19.17 \%$ & 1 & \\
\hline PV & \multirow{3}{*}{$15 \%$} & 11.25 & Reject: $10.15 \%$ & - & \multirow{3}{*}{$\begin{array}{l}(\mathrm{WT}, \mathrm{DG})=41.10 \%>14 \% \\
\text { Decision: Choose WT }\end{array}$} \\
\hline WT & & 21.43 & Accept: $26.98 \%$ & 2 & \\
\hline DG & & 18.35 & Accept: $17.92 \%$ & 1 & \\
\hline PV & \multirow{3}{*}{$20 \%$} & 11.22 & Reject: $10.12 \%$ & - & \multirow{3}{*}{$\begin{array}{l}(\mathrm{WT}, \mathrm{DG})=42.16 \%>14 \% \\
\text { Decision: Choose WT }\end{array}$} \\
\hline WT & & 21.37 & Accept: $26.84 \%$ & 2 & \\
\hline DG & & 18.11 & Accept: 16.71\%: & 1 & \\
\hline
\end{tabular}



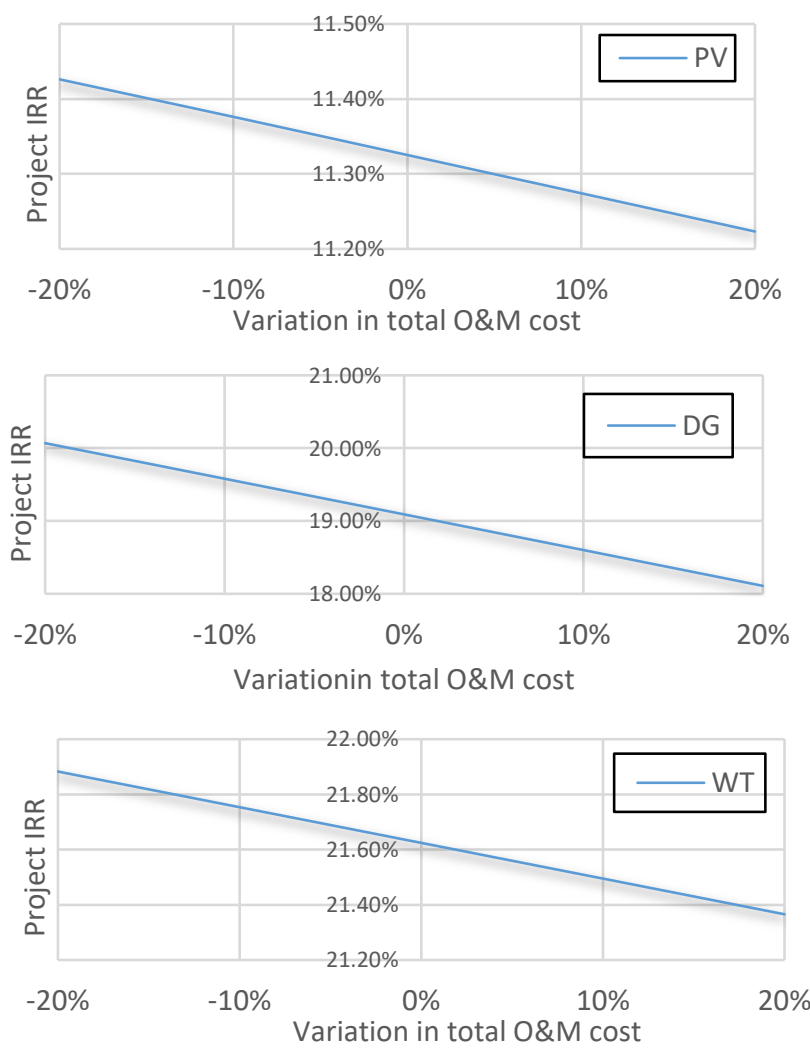

Figure 7. Sensitivity analysis of operation and maintenance (O\&M) cost variation effect on project IRR.

The effect of the variation of the cost of diesel fuel on the decision towards selecting the best project for an investment is studied as shown in Table 6.

Table 6. $1 \mathrm{MW}$ diesel cost variation effect on IRR and decision-making.

\begin{tabular}{|c|c|c|c|c|c|}
\hline Variation in price & $-5 \%$ & $-2.5 \%$ & 0 & $2.5 \%$ & $5 \%$ \\
\hline Project IRR & $23.48 \%$ & $21.32 \%$ & $19.09 \%$ & $16.76 \%$ & $14.18 \%$ \\
\hline Equity IRR & $22.78 \%$ & $22.52 \%$ & $22.27 \%$ & $22.01 \%$ & $21.75 \%$ \\
\hline $\begin{array}{c}\text { Order based on } \bar{C} \text { compared to } \\
\text { other projects }\end{array}$ & - & 1 & 1 & 1 & 1 \\
\hline$\triangle I R R$ & Cannot be determined & $23.82 \%$ & $37.88 \%$ & $51.22 \%$ & $68.35 \%$ \\
\hline Decision & $\begin{array}{l}\text { Follow benefit to cost ratio } \\
\text { technique (Section 9) }\end{array}$ & WT & WT & WT & WT \\
\hline
\end{tabular}

\section{Incremental Benefit to Cost Ratio for Sensitivity Analysis on Diesel Cost Variation}

When the decision cannot be determined based on the incremental rate of return analysis due to the negative cash flows coming after the positive cash flows somewhere in the middle of the project cash flow, one of the following two methods can be used. The first is to consider the modified incremental rate of return, as in [41], and the second one is to use the incremental benefit to cost ratio method explained in [41] and also presented in [71,72]. In this paper, the second method, described in Figure 8, will be applied, as the first method requires knowledge of the investment return that is not presently available. In the case of decreasing the current fuel cost by $5 \%$, the incremental benefit to cost ratio is used to select the project to be considered as an investment when considering the comparison among wind project and diesel generator project. It is important to emphasize that both the present worth of benefits (B) and the present worth of costs (C) are calculated based on the after-tax cash flows of the projects. 


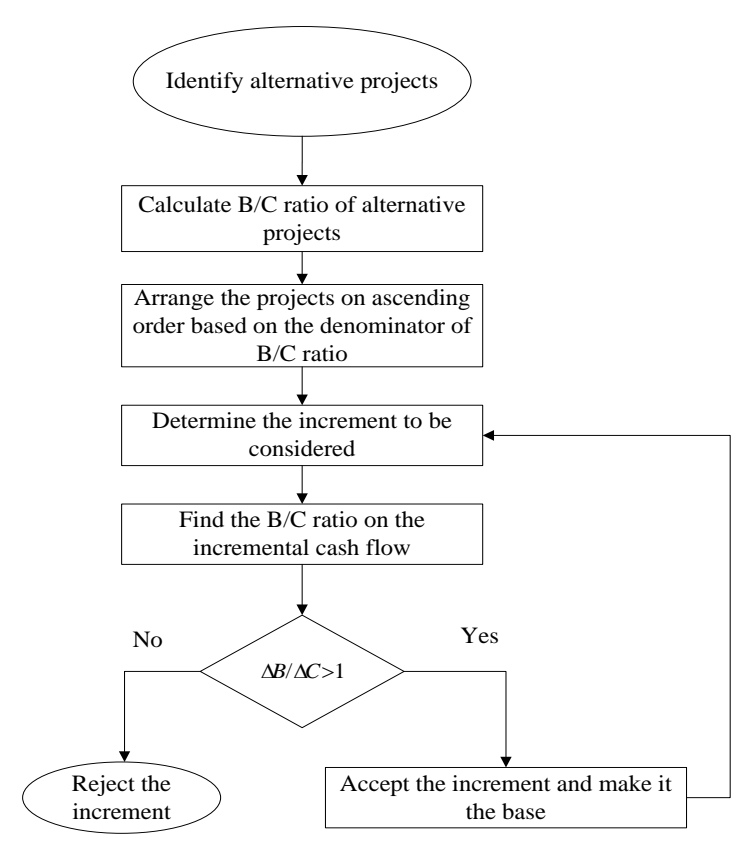

Figure 8. Incremental benefit to cost ratio analysis.

For the wind project, the present value of costs is INR 38,608,237.50, and the present value of benefits is INR 61,612,644.60. On the other hand, the diesel generator project has a present value of costs of INR 33,340,310.19 and a present value of benefits of INR 59,084,442.53. Based on these values, the benefit to cost ratio is 1.60 for the wind project, and it is 1.77 for the diesel generator project. Both projects are considered for further analysis, as the $\mathrm{B} / \mathrm{C}$ ratios were determined to be greater than one; otherwise, the alternative is to be eliminated if this condition is not met.

The increment under consideration is recognized as moving from the "diesel generator project" to "wind project" as an alternative project, since the former has a lower present value of costs.

$\Delta B$ in Equation (11) and $\Delta C$ in Equation (12) are calculated based on (Cash $(n)$ Wind - Cash $\left.(n)_{\text {Diesel }}\right)$, where ' $F_{b}$ ' is the future benefit, and ' $F_{C}$ ' is the future cost. It is found that the result of Equation (11) is INR 2,648,409.96, while the value of Equation (12) is INR 5,388,135.20. The incremental B/C is used to make a decision with respect to the project to be selected. This increment is found to be 0.49 . Since this value is less than one, the wind project is disregarded, and the diesel generator project is to be considered when the fuel cost is reduced by $5 \%$.

$$
\begin{gathered}
\triangle B=\sum \frac{F_{b}(n)}{(M A R R+1)^{n}} \\
\triangle C=\left|\sum \frac{F_{C}(n)}{(M A R R+1)^{n}}\right|
\end{gathered}
$$

\section{Economic Analysis of the Projects: A Comparison with the Literature}

Some investors determine the internal rate of return by considering the total cost of the project, which is composed of debt and equity, as described in [23]. In this case, the economic analysis performed on the project's cash flows is defined as described in the previous sections. On the other hand, other investors find the internal rate of return by only accounting for the equity component at year zero, as performed in [26,73]. In this case, the promoters' contribution is more concerned. This cash flow is defined as the private cash flow based on [63]. In the previous sections, this definition was applied to determine the equity internal rate of return. 
An alternative definition of the project internal rate of return was stated in [63], where the cash flows of individual projects signify the difference between revenues and expenses every year in consideration of the project capital cost and disregarding factors such as depreciation, taxes, debt repayment and interest. Such a definition can have an effect on the incremental internal rate of return and, thus, the decision to invest in a project. This was investigated by assuming a $\pm 20 \%$ variation in either the capital cost of the project or the operation and maintenance costs. When such variations are applied on the project capital cost, wind turbines remain in the top position among the studied projects. The incremental internal rate of return varied between $61.87 \%$, when comparing wind and diesel generator projects, and $10.68 \%$, when comparing wind and PV projects, when the variation in the capital cost was $-20 \%$. This value is equal to $42.34 \%$ when comparing wind and diesel generator projects at $+20 \%$ variation in the capital costs. In the latter case, the equity IRR of PV projects was below the equity MACRS, and thus was not considered for further investigation in the incremental rate of return analysis. This led to the wind turbine being retained as the best investment project. On the other hand, when such variations were considered with respect to the operation and maintenance costs, the incremental internal rate of return varied between $43.78 \%$ and $56.56 \%$. In this case, only the wind turbine and diesel generator projects were compared, since the PV project was rejected because its equity internal rate of return is below the minimum accepted equity rate of return.

Furthermore, the effect of a $\pm 5 \%$ fuel cost variation in diesel price for the diesel generator project when deciding on the best economic project was considered following the definition of project cash flow provided in [63]. It was found that when comparing the available investment options, the diesel generator project was the best alternative, since the ratio was found to be 0.4 , making the diesel generator project, which has the lowest present cost value, the selected investment project at $-5 \%$ variation of fuel cost.

Other components of project cash flow are treated differently in the literature/practice. The effect of such differences on the decision to invest in a project has been investigated as summarized below:

Project depreciation tax basis was defined in [40]. Reference [40] considered the percentage to be depreciated from the project capital cost along the project life span considering both straight line and declining balance depreciations. Reference [26] applied the concept in [40] and used 90\% as the depreciation tax basis. The rest $(10 \%)$ is assumed to be expenditure at year zero. In this case, taxation is considered at all years, including year zero. For year zero, the tax rate is multiplied by the difference between any profits and grants and the $10 \%$ already depreciated amount. The results obtained considering the effect of such contemplation on the project IRR, calculated for cash flow considering the capital cost of project at year zero, interest paid, depreciation and liable taxes, are presented in Table 7 and are referred to as "Definition A". It can be noticed from this table that the wind project is a superior economic project in comparison to solar PV the diesel generator projects when considering such an investment for power generation. 
Table 7. Economic analysis of projects: a comparison with the literature.

A) IRR of Projects under "Definition A" of project depreciation tax basis in [26] compared to MACRS

\begin{tabular}{cccccccc}
\hline & \multicolumn{2}{c}{ Equity IRR\% } & \multicolumn{4}{c}{ Project IRR \% } \\
\hline Depreciation & MACRS & $\begin{array}{c}\text { Declining } \\
\text { balance }\end{array}$ & $\begin{array}{c}\text { Straight } \\
\text { line }\end{array}$ & Depreciation & MACRS & $\begin{array}{c}\text { Declining } \\
\text { balance }\end{array}$ & $\begin{array}{c}\text { Straight } \\
\text { line }\end{array}$ \\
\hline 1 MW WT & 28.50 & 32.05 & 27.55 & WT & 22.00 & 23.30 & 21.62 \\
1 MW PV & 10.30 & 10.58 & 10.07 & PV & 11.48 & 11.58 & 11.18 \\
1 MW DG & 22.85 & 24.65 & 22.16 & DG & 19.35 & 20.20 & 19.01 \\
\hline Based on & Reject PV & Reject PV & Reject PV & Incremental & (WT, DG) & (WT, DG) & $($ WT, DG) \\
\cline { 5 - 9 } & & & & Decision & wind & wind & Wind \\
\hline
\end{tabular}

B) IRR of projects under "Definition B" of depreciation and salvage value compared to MACRS

\begin{tabular}{lccccccc}
\hline & \multicolumn{2}{c}{ Equity IRR\% } & \multicolumn{4}{c}{ Project IRR \% } \\
\hline Depreciation & MACRS & $\begin{array}{c}\text { Declining } \\
\text { balance }\end{array}$ & $\begin{array}{c}\text { Straight } \\
\text { line }\end{array}$ & Depreciation & MACRS & $\begin{array}{c}\text { Declining } \\
\text { balance }\end{array}$ & $\begin{array}{c}\text { Straight } \\
\text { line }\end{array}$ \\
\hline 1 MW WT & 27.39 & 31.80 & 26.18 & WT & 21.62 & 23.19 & 21.10 \\
1 MW PV & 10.25 & 10.54 & 9.95 & PV & 11.33 & 11.55 & 11.08 \\
1 MW DG & 22.27 & 24.44 & 21.30 & DG & 19.09 & 20.09 & 18.60 \\
\hline Based on & \multirow{2}{*}{ Reject PV } & Reject PV & Reject PV & Incremental & (WT, DG) & (WT, DG) & (WT, DG) \\
\cline { 4 - 8 } equity IRR & & & & Decision & wind & wind & Wind \\
\hline
\end{tabular}

C) IRR of projects under "Definition C" of depreciation considering the $50 \%$ rule

\begin{tabular}{cccccccc}
\hline & \multicolumn{2}{c}{ Equity IRR\% } & \multicolumn{4}{c}{ Project IRR\% } \\
\hline Depreciation & MACRS & $\begin{array}{c}\text { Declining } \\
\text { balance }\end{array}$ & $\begin{array}{c}\text { Straight } \\
\text { line }\end{array}$ & Depreciation & MACRS & $\begin{array}{c}\text { Declining } \\
\text { balance }\end{array}$ & $\begin{array}{c}\text { Straight } \\
\text { line }\end{array}$ \\
\hline 1 MW WT & 25.57 & 31.95 & 25.12 & WT & 20.79 & 21.02 & 20.59 \\
1 MW PV & 9.32 & 10.57 & 9.16 & PV & 10.62 & 11.58 & 10.49 \\
1 MW DG & 20.75 & 24.61 & 20.39 & DG & 18.27 & 20.18 & 18.08 \\
\hline Based on & \multirow{2}{*}{ Reject PV } & Reject PV & Reject PV & Incremental & (WT, DG) & (WT, DG) & (WT, DG) \\
equity IRR & & & & IRR & $=36.98 \%$ & $=28.23 \%$ & $=36.74 \%$. \\
\cline { 4 - 8 } & & & & Decision & wind & wind & wind \\
\hline
\end{tabular}

D) IRR of projects under "Definition D" of project depreciation and salvage value

\begin{tabular}{lccccccc}
\hline & \multicolumn{2}{c}{ Equity IRR $\%$} & \multicolumn{4}{c}{ Project IRR\% } \\
\hline Depreciation & MACRS & $\begin{array}{c}\text { Declining } \\
\text { balance }\end{array}$ & $\begin{array}{c}\text { Straight } \\
\text { line }\end{array}$ & Depreciation & MACRS & $\begin{array}{c}\text { Declining } \\
\text { balance }\end{array}$ & $\begin{array}{c}\text { Straight } \\
\text { line }\end{array}$ \\
\hline 1 MW WT & 27.39 & 27.09 & 25.75 & WT & 21.62 & 21.47 & 20.92 \\
1 MW PV & 10.25 & 10.22 & 9.91 & PV & 11.33 & 11.27 & 11.02 \\
1 MW DG & 22.27 & 22.50 & 21.15 & 24.61 & 19.09 & 19.19 & 18.52 \\
\hline Based on & \multirow{2}{*}{ Reject PV } & Reject PV & Reject PV & Incremental & (WT, DG) & (WT, DG) & $($ WT, DG) \\
equity IRR & & & & IRR & $=37.88 \%$ & $=35.76 \%$ & $=36.25 \%$ \\
\cline { 4 - 8 } & & & & Decision & wind & wind & wind \\
\hline
\end{tabular}

E) IRR of projects under "Definition E" of project depreciation and salvage value

\begin{tabular}{lccccccc}
\hline & \multicolumn{2}{c}{ Equity IRR $\%$} & \multicolumn{4}{c}{ Project IRR $\%$} \\
\hline Depreciation & MACRS & $\begin{array}{c}\text { Declining } \\
\text { balance }\end{array}$ & $\begin{array}{c}\text { Straight } \\
\text { line }\end{array}$ & Depreciation & MACRS & $\begin{array}{c}\text { Declining } \\
\text { balance }\end{array}$ & $\begin{array}{c}\text { Straight } \\
\text { line }\end{array}$ \\
\hline 1 MW WT & 27.39 & 27.09 & 25.90 & WT & 21.62 & 21.47 & 20.98 \\
1 MW PV & 10.25 & 10.18 & 9.93 & PV & 11.33 & 11.25 & 11.04 \\
1 MW DG & 22.27 & 22.49 & 21.25 & DG & 19.09 & 19.19 & 18.57 \\
\hline Based on & \multirow{2}{*}{ Reject PV } & Reject PV & Reject PV & Incremental & (WT, DG) & (WT, DG) & $($ WT, DG) \\
equity IRR & & & & IRR & $=37.88 \%$ & $=35.76 \%$ & $=36.41 \%$ \\
\cline { 4 - 8 } & & & & Decision & wind & wind & wind \\
\hline
\end{tabular}


Depreciation tax basis is the amount that needs to be subtracted from the project net cash flow for the tax basis. Such an amount forms $90 \%$ of the capital cost of a project. Once depreciation has been applied to the project cash flow, the depreciation amount should constitute $90 \%$ of the project's capital cost over its cash flow span. The undepreciated $10 \%$ is not to be experienced at year zero, as it is defined to be scrap, or what is known as salvage value [74]. The salvage value of a project is recognized as a gain, which some studies, such as $[26,40]$ have not considered, assuming the book value of the project to be fully depreciated when the project is terminated. This concept is further explained in $[24,41]$. The above concepts are referred to as "Definition B", and Table 7 shows how this can influence the project internal rate of return. It is essential to clarify that MACRS depends on zero salvage value at the last year of depreciation. Therefore, $100 \%$ depreciation is only considered when MACRS depreciation is considered. Furthermore, the salvage value is anticipated to be the same as the book value. The tax charged on the difference between two such values is zero. The salvage value needs to be added to the after-tax cash flow in the final year of the operation of the project commercially. This follows the idea of gains tax, as explained in $[75,76]$. On the other hand, when the declining balance depreciation, as described in [26,40], is carried out such that the depreciation rate is applied to each year of the project cash flow excluding the final year while applying the concept of $90 \%$ depreciation as defined in [24,74], the depreciation rate will be followed up until year 6 . In this case, the amount of depreciation at year 7 is calculated such that the summation of depreciation from year 1 to year 6 will form $90 \%$ of the project capital cost. For successive years, the depreciation amount will be zero, while the book value will retain its value until the final year of commercial operation of the project. This concept is thoroughly explained in [41].

When the taxation system described in $[26,40]$ is applied, depreciation is taken into account; however, the $50 \%$ rule for depreciation, described in [77], will not be considered. This rule describes the amount to be depreciated if expenses are encountered at year zero. On the other hand, if income is received, then the project's total capital cost will be depreciated. Such an effect is considered by involving the three depreciation methods in order to investigate their effects on selecting the best project to invest in from an economic perspective, as shown in Table 7, and such concepts are referred to as "Definition C".

Declining balance depreciation rate, discussed in [26,40], is specified in consideration of the policy regulating the project's cash flow. On the other hand, there exists a distinct category recognized as $150 \%$ declining balance depreciation, which will be used here for the purpose of comparison with MACRS depreciation effect on the decision to invest in one project among possible alternatives. The reason behind choosing a 150\% declining balance depreciation to be compared with MACRS depreciation is due to the well-recognized fact in the literature that MACRS delivers more deductions for tax purposes. Accordingly, if declining balance depreciation is used for evaluation reasons, the declining balance depreciation rate is to be set precisely in such a way that it does not contradict the MACRS deductions. As a clarification, declining balance depreciation rate might provide supplementary effectiveness, since such a rate can be set following a policy regulating the project financial structure. As a result, when a comparison is concerned, a base line is to be specified such that the comparison can be performed. At this instant, the base line is what is recognized in the literature as the $150 \%$ decline balance depreciation. Reference [78] illustrates the declining balance method which is to be considered for comparisons with both MACRS and straight line depreciation methods when applied to projects' cash flows. This clarifies that the declining balance depreciation rate is to track that of MACRS in consideration of the property class. Because the projects under study belong to the 20 year property class, since their life span is 25 years, the rate of declining balance depreciation is to be specified as $150 \%$, and the number of years under consideration is 25 years. It is important to clarify that the amount of depreciation, ' $\omega$ ', is to be found until year 21 such that it is consistent with MACRS depreciation. In contrast, straight line depreciation is to be carried out until year 25 . The effect of such consideration on the decision to select a given project for investment among possible alternatives is investigated as shown in Table 7, and the above concepts are referred to as "Definition D". Equation 
(13) is applied to find the amount of yearly depreciation. ' $\bar{r}$ ' is the year number when the depreciation value is to be deducted, and 'Book' in the below equation indicates the project book value defined as the project cost at year zero based on [41]. At this instance, the salvage value is presumed to be the book value. As a result, no taxes will be charged at year 25 on the difference between the salvage value and the book value; however, the salvage value will be set as a gain to the after-tax cash flow at this year when applying a 150\% declining balance depreciation.

$$
\bar{\omega}(n)=\left\{\begin{array}{c}
\frac{1.5}{25 y \text { years }} *(\text { Book }) \forall n=1 \\
\frac{1.5}{25 \text { years }} *\left(\text { Book }-\sum_{\bar{r}=1}^{n-1} \bar{\omega}(n)\right) \forall 2 \leq n \leq 21
\end{array}\right.
$$

Reference [41] considers the depreciation to be carried out up to the year when the undepreciated amount of the capital cost of the project is equivalent to the salvage value. Therefore, a $150 \%$ declining balance depreciation is considered up until year 25. The undepreciated amount recognized as the book value is presumed to have the same value as the salvage value. This postulation is taken into consideration when applying the straight line depreciation, as well. The effect of this on the decision to invest in a project among several possible alternatives is investigated as shown in Table 7, and the above concepts are referred to as "Definition E". From an economic perspective, it can be seen from this table that the wind project continues to be the top project among the candidates for investment in the power generation sector.

\section{Distributed Generation Technologies and Policy Implications}

One of the major challenges associated with the generation of power from renewable energy sources is their uncertain behavior. Power generation from renewable energy sources is driven by weather factors, such as wind speed, solar irradiance, etc. [9,23,33], and the timing of the intermittent resource availability. In addition, the type of technology is another factor governing the amount of power that can be generated from renewable energy systems. To overcome this uncertainty in power generation in renewable energy systems, secondary power options such as energy storage systems may be required, depending the purpose of the renewable energy system and the installation site [79]. Solar and wind energy are far different as stand-alone power supplies (as might be the case in a remote village) from cases in which they are plants supplementing the grid (or can be supplemented by it.) Therefore, the ratings of such technologies, the requirement for energy storage systems, and the type of energy storage systems would differ. For instance, the authors of [80] indicated that small wind turbines of $(<50 \mathrm{~kW})$ were suitable for stand-alone application, such as in the case of electrifying small villages in developing countries, while larger wind turbines could be effective when dealing with remote communities in developed countries. Reference [79] provided more detail on categorizing the rating of wind systems. If the purpose behind a wind project is battery charging, region lighting, supplying electricity to small remote areas, and off-grid applications, the rating of the wind system will be less than $5 \mathrm{~kW}$. Such a value can be in the range from 1-10 $\mathrm{kW}$ when considering residential and small-scale business that are connected to the grid. For the case of farms and institutional grid connected applications, the rating could be more than $300 \mathrm{~kW}$ [79].

Sizing the energy storage system is another topic that lies beyond the scope of this paper; however, it is important to highlight that the size of energy storage in the case of a stand-alone solar PV system is subject to the parameters of the storage system, the targeted application, and the concept of system availability [81]. Some grid-tied systems do not have a storage system, as the solar system uses grid-tied inverters, and such systems are applicable for grid-connected customers with residential solar installations in order to attain less electricity bills. Other grid-tied systems have battery storage as a back-up, which is useful for grid-connected customers who experience power outages. There are also battery storage systems for off-grid electrification and remote communities [82]. 
The power capacity of storage technologies with renewable energy technology should be (10 kW-100 MW) with less than a 1 second response time and (100-1000 yearly cycles) [83]. In general, pumped-hydroelectric energy storage, underground pumped-hydroelectric energy storage and compressed air energy storage are used when the required power and the energy capacity are greater than $50 \mathrm{MW}$ and100 MWh, respectively. Battery energy storage and flow battery energy storage systems are suitable for (1-50 MW) power and storage capacities of (5-100 MWh). Supercapacitors, flywheels and superconducting magnetic energy storage systems are useful for medium-scale power or storage capacities. Hydrogen energy storage systems, thermal energy storage systems and electric vehicles are suitable when there is a demand for small energy storage systems [83]. Thus, subject to the investor's application of the renewable energy system (managing the demand side, spinning reserve, stabilizing both transmission and distribution, deferring the upgrade of transmission, generating on-peak power, integrating RE, backups in case of emergency, etc.), the choice of energy storage system type, size and capacity can vary [83]. In addition, this would also have a significant impact on the cost of technology, and can influence the decision to invest in the renewable energy sector. In our case study, the storage system is used for renewable energy integration and it is important to clarify that a $1 \mathrm{MW}$ renewable energy project is not necessarily the rating of one system only, but it could be the result of an aggregation of small-scale energy systems. In this paper, the cost of the energy storage system is assumed to be part of the rest of the system cost, and such a cost can vary. The impact of this cost on the decision to invest is set as a target for future work.

Policy makers and regulators should take fast action to move forward with the rapid changes in technology and the growing demand for flexibility in the power system. Matters including storage market design, the electric vehicle/grid interface and confidentiality of data all have the potential to expose customers to new risks [50], thus necessitating further research. Policies are needed to enable energy storage to be a player in the market such that it can cover its costs through the benefits it provides to the power network [84]. In many countries, charging/discharging prices can vary based on the time of the day; however, the Indian scenario is based on the unit pricing system and defined for the long term [22]. Tariff revision and incentives are necessary to enhance the deployment of energy storage systems given the variety of services it can provide. Regulators' decisions can be influenced by the emission effect of storage systems. Thus, social cost-benefit analysis is recommended to enhance the decision-making process while considering such factors. This analysis is to be considered carefully, taking into account all benefits and possible effects on emissions over the long run of the projects [85]. In addition, policies enabling diversity in the energy storage system ownership and operational stakeholders are encouraged [84]. The end users of the energy from the storage should be defined, as the price of electricity is calculated at the rate of the wholesale market when storage is charged from the grid and then discharged back to the grid for capacity, ancillary service, etc. On the other hand, when the storage is behind the meter, the price of charging is calculated at the rate of the retail market, which is recognized to be flat. Therefore, more studies are needed related to effective price signals [85].

\section{Conclusions}

Limited fuel resources and limited local income are two major challenges faced by the power sector. With the global tension on developing countries towards a green mix of supply, there are some renewable energy projects established in these countries; however, the application and use of such resources is limited to a small percentage of their potential. This paper provided a study that can assist investors in selecting the best investment project based on an economic analysis by providing a comparison based on the incremental internal rate of return analysis and the incremental benefit to cost ratio analysis. PV, wind turbine, and diesel generator projects were compared. In general, the wind energy project maintained superiority over other projects in the considered Maharashtra-Indian case study. The study revealed that the present value of the costs for the wind energy project was INR 38,608,237.50, while the present value of the benefits was INR 61,612,644.60. According to the incremental rate of return analysis, the wind project was compared to the diesel power generation 
project after rejecting the PV project, whose equity internal rate of return was less than $14 \%$ (the minimum accepted equity rate of return).

The comparison showed that the incremental rate of return was $45.74 \%$ when comparing first the wind energy project to the diesel power generation project, and $9.56 \%$ when comparing the former project to the PV energy project, for a $20 \%$ reduction in the capital cost of the project. These values provide guidance for selecting the wind energy project over the other projects in accordance with the criterion of exceeding the minimum accepted rate of return. With an increase in the capital cost of $20 \%$, the PV project was rejected, as its equity internal rate of return $(7.96 \%)$ was less than its equity MARR, leaving the comparison to be between the wind and diesel energy projects. In this case, the incremental internal rate of return was found to be $32.78 \%$, and thus, the wind energy project revealed its value over a long duration of operation. The same conclusion was arrived at when the operation and maintenance costs were allowed to vary between $-20 \%$ and $20 \%$. On the other hand, diesel power generation was superior to the other projects when its fuel cost was reduced by $5 \%$, as demonstrated by the incremental benefit to cost ratio technique. In general, the cash flow structure was subject to the definition of its components or the approaches for dealing with such components. The paper reviewed these other definitions/approaches, which have been applied in the literature to the cash flows of individual projects as regulations governing the financial structure of the project, and used these regulations to provide a comparison of the significance of such regulations in selecting a project for investment among several possible alternatives. It was found that the wind project remained at the top of the projects for investment where value for money was concerned, and limited local funds were considered under different depreciation methods. The uncertainty of renewable energy may necessitate the demand for energy storage systems that are subject to the type of application. There are many policy implications when considering the energy storage system and these implications can affect the decision towards an investment in the renewable energy sector. Studying such an impact necessitates further research and set as a goal of future research.

Author Contributions: Conceptualization, A.S.A.-S. and M.S.; formal analysis, A.S.A.-S.; investigation, A.S.A.-S.; writing-original draft preparation, A.S.A.-S., S.R., M.P.; writing-review and editing, A.S.A.-S., M.S., S.R., M.P., A.K.-F. and M.B.R.; visualization, A.S.A.-S., S.R., M.P. and A.K.-F.; supervision, A.S.A.-S. and M.S.; project administration, A.S.A.-S. and M.S.; funding acquisition, A.S.A.-S. All authors have read and agreed to the published version of the manuscript.

Funding: This research was funded by Khalifa University under grant number "FSU-2018-25" and earlier by Masdar Institute.

Conflicts of Interest: The authors declare no conflict of interest. The funders had no role in the design of the study; in the collection, analyses, or interpretation of data; in the writing of the manuscript, or in the decision to publish the results.

\section{References}

1. Al-Sumaiti, A.; Salama, M.M.A. Review on Issues Related to Electric Energy Demand in Distribution System for Developing Countries. In Proceedings of the 3rd IET International Conference on Clean Energy and Technology, Kuching, Sarawak, Malaysia, 24-26 November 2014. [CrossRef]

2. World Energy Council-Indian Member Committee (WEC-IMC) and Power Grid Corporation of India Limited. Transmission and Distribution in India: A Report; A Joint Initiative of WECIMC and Power Grid Corporation of India Limited: India. Available online: http://npti.gov.in/sites/default/files/download-document/world_ energy_council_report.pdf (accessed on 22 May 2020).

3. REN21 Renewable Energy Policy Network for the 21st Century. Renewables 2018 Global Status Report, REN21. (Paris: REN21 Secretariat). 2018. Available online: https://www.ren21.net/wp-content/uploads/2019/ 05/GSR2018_Full-Report_English.pdf (accessed on 17 April 2020).

4. Al-Sumaiti, A.S.; Salama, M.M.; El Moursi, M.S. Enabling electricity access in developing countries: A probabilistic weather driven house based approach. Appl. Energy 2017, 191, 531-548. [CrossRef] 
5. Al-Sumaiti, A.S.; Salama, M.; El Moursi, M.; Alsumaiti, T.S.; Marzband, M. Enabling electricity access: Revisiting load models for AC-grid operation-Part, I. IET Gener. Transm. Distrib. 2019, 13, 2563-2571. [CrossRef]

6. Al-Sumaiti, A.S.; Salama, M.; El Moursi, M.; Alsumaiti, T.S.; Marzband, M. Enabling electricity access: A comprehensive energy efficient approach mitigating climate/weather variability-Part II. IET Gener. Transm. Distrib. 2019, 13, 2572-2583. [CrossRef]

7. Konda, S.R.; Al-Sumaiti, A.S.; Panwar, L.K.; Panigrahi, B.K.; Kumar, R. Impact of Load Profile on Dynamic Interactions Between Energy Markets: A Case Study of Power Exchange and Demand Response Exchange. IEEE Trans. Ind. Inform. 2019, 15, 5855-5866. [CrossRef]

8. Reddy, S.; Al Sumaiti, A.; Panwar, L.; Panigrahi, B.K.; Kumar, R. An Online Adaptive Intelligent Framework for Customer Willingness Interpretation in Demand Response Exchange. In Proceedings of the 2018 8th IEEE India International Conference on Power Electronics (IICPE), Institute of Electrical and Electronics Engineers (IEEE), Jaipur, India, 13-15 December 2018; pp. 1-6.

9. Al-Sumaiti, A.S.; Ahmed, M.H.; Salama, M. Residential Load Management under Stochastic Weather Condition in Developing Countries. Electr. Power Components Syst. 2014, 42, 1452-1473. [CrossRef]

10. Li, Q.; Yu, S.; Al-Sumaiti, A.; Turitsyn, K. Modeling and Co-Renewable Energy Policy Network for the 21st Century Optimization of A Micro Water-Energy Nexus for Smart Communities. In Proceedings of the 2018 IEEE PES Innovative Smart Grid Technologies Conference Europe (ISGT-Europe), Sarajevo, Bosnia-Herzegovina, 21-25 October 2018.

11. Nguyen, H.; Al-Sumaiti, A.S.; Turitsyn, K.; Li, Q.; El Moursi, M.S. Further Optimized Scheduling of Micro Grids via Dispatching Virtual Electricity Storage Offered by Deferrable Power-Driven Demands. IEEE Trans. Power Syst. 2020, 1. [CrossRef]

12. Mohandes, B.; Acharya, S.; El Moursi, M.S.; Al-Sumaiti, A.; Doukas, H.; Sgouridis, S. Optimal Design of an Islanded Microgrid with Load Shifting Mechanism Between Electrical and Thermal Energy Storage Systems. IEEE Trans. Power Syst. 2020, 1. [CrossRef]

13. Singh, R.; Sood, Y.R.; Padhy, N.P. Development of renewable energy sources for indian power sector moving towards competitive electricity market. In Proceedings of the 2009 IEEE Power \& Energy Society General Meeting, Calgary, AB, Canada, 26-30 July 2009; pp. 1-6. [CrossRef]

14. Asgher, U.; Rasheed, M.B.; Al-Sumaiti, A.S.; Rahman, A.U.; Ali, I.; Alzaidi, A.; Alamri, A. Smart Energy Optimization Using Heuristic Algorithm in Smart Grid with Integration of Solar Energy Sources. Energies 2018, 11, 3494. [CrossRef]

15. Javadi, M.; Marzband, M.; Akorede, M.; Godina, R.; Al-Sumaiti, A.S.; Pouresmaeil, E. A Centralized Smart Decision-Making Hierarchical Interactive Architecture for Multiple Home Microgrids in Retail Electricity Market. Energies 2018, 11, 3144. [CrossRef]

16. Fouladfar, M.H.; AlSumaiti, A.; Fenik, M.S.; Marzband, M.; Busawon, K.; Pouresmaeil, E. Energy Management of a Single Grid-Connected Home Microgrid for Determining Optimal Supply/Demand Bids. In Proceedings of the 2018 5th International Symposium on Environment-Friendly Energies and Applications (EFEA), Rome, Italy, 24-26 September 2018; pp. 1-8. [CrossRef]

17. Al-Sumaiti, A.S.; Ahmed, M.H.; Salama, M.M.A. Smart Home Activities: A Literature Review. Electr. Power Components Syst. 2014, 42, 294-305. [CrossRef]

18. Khatib, H. Renewable Energy in Developing Countries. In Proceedings of the International Conference on Renewable Energy-Clean Power 2001, IET, London, UK, 17-19 November 1993.

19. Li, Q.; Yu, S.; Al-Sumaiti, A.; Turitsyn, K. Modeling and Co-Optimization of a Micro Water-Energy Nexus for Smart Communities. In Proceedings of the 2018 IEEE PES Innovative Smart Grid Technologies Conference Europe (ISGT-Europe), Sarajevo, Bosnia-Herzegovina, 21-25 October 2018; Volume 6, pp. 1-5. [CrossRef]

20. Banhidarah, A.K.; Al-Sumaiti, A.S. Heuristic search algorithms for optimal locations and sizing of distributed generators in the grid: A brief recent review. In Proceedings of the 2018 Advances in Science and Engineering Technology International Conferences (ASET), Institute of Electrical and Electronics Engineers (IEEE), Abu Dhabi, United Arab Emirates, 6 February-5 April 2018; pp. 1-5.

21. Al-Sumaiti, A.S. The role of regulation in the economic evaluation of renewable energy investments in developing countries. In Proceedings of the 2013 7th IEEE GCC Conference and Exhibition (GCC), Institute of Electrical and Electronics Engineers (IEEE), Doha, Qatar, 17-20 November 2013; pp. 39-43. 
22. Al-Sumaiti, A.S.; Salama, M.M.A.; Konda, S.R.; Kavousi-Fard, A.; Konda, S.R. A Guided Procedure for Governance Institutions to Regulate Funding Requirements of Solar PV Projects. IEEE Access 2019, 7, 54203-54217. [CrossRef]

23. Al-Sumaiti, A.S. Power Generation Shortage in Developing Countries: Causes, Challenges and Solutions. Ph.D. Thesis, University of Waterloo, Waterloo, ON, Canada, 2015.

24. Deo, P.; Jayaraman, S.S.; Verma, S.V.S.; Dayalan, S.M.D. In the Matter of Determination of Generic Levellised Generation Tariff for the FY2013-14 under Regulation 8 of the Central Electricity Regulatory Commission (Terms and Conditions for Tariff Determination from Renewable Energy Sources) Regulations. Central Electricity Regulatory Commission, New Delhi, India, Petition No. 243/SM/2012 (Suo-Motu). 2012. Available online: http://www.cercind.gov.in/2013/orders/SO243.pdf (accessed on 17 April 2020).

25. Lalwani, M.; Kothari, D.P.; Singh, M. Viability Analysis by Techno-Economic Aspects of Grid Interactive Solar Photovoltaic Project in India. In Proceedings of the International Conference on Advances in Engineering Science and Management (ICASEM), Nagapattinam, Tamil Nadu, India, 30-31 March 2012; pp. 769-772.

26. Natural Resources Canada. Teacher's Note: Wind Energy Project (Grid Connected Wind Farm, Andhara Pradesh, India). Available online: www.retscreen.net/download.php/ang/33/2/WIND04-B.pdf (accessed on 28 May 2013).

27. Noori, M.; Kucukvar, M.; Tatari, O. Economic Input-Output Based Sustainability Analysis of Onshore and Offshore Wind Energy Systems. Int. J. Green Energy 2014, 12, 939-948. [CrossRef]

28. Castro-Santos, L.; Casas, V.D. Sensitivity analysis of floating offshore wind farms. Energy Convers. Manag. 2015, 101, 271-277. [CrossRef]

29. IRENA. Renewable Energy Analysis: Cost Analysis Series. 2012. Available online: https://www.irena.org/ (accessed on 28 May 2020).

30. Conover, K. Photovoltaic operation and maintenance evaluation. IEEE Trans. Energy Convers. 1990, 5, 279-283. [CrossRef]

31. Shukla, A.K.; Sudhakar, K.; Baredar, P. Design, simulation and economic analysis of standalone roof top solar PV system in India. Sol. Energy 2016, 136, 437-449. [CrossRef]

32. Rodrigues, S.; Torabi, R.; Faria, F.; Cafôfo, N.; Chen, X.; Ivaki, A.R.; Mata-Lima, H.; Morgado-Dias, F. Economic feasibility analysis of small scale PV systems in different countries. Sol. Energy 2016, 131, 81-95. [CrossRef]

33. Al-Sumaiti, A.S.; Hassan, M.A.; Rivera, S.; Salama, M.A.A.; El Moursi, M.S.; Alsumaiti, T. A Stochastic PV Model for Power System Planning Applications. IET Renew. Power Gener. 2019, 13, 3168-3179. [CrossRef]

34. Blechinger, P.; Cader, C.; Bertheau, P.; Huyskens, H.; Seguin, R.; Breyer, C. Global analysis of the techno-economic potential of renewable energy hybrid systems on small islands. Energy Policy 2016, 98, 674-687. [CrossRef]

35. Mamaghani, A.H.; Escandon, S.A.A.; Najafi, B.; Shirazi, A.; Rinaldi, F. Techno-economic feasibility of photovoltaic, wind, diesel and hybrid electrification systems for off-grid rural electrification in Colombia. Renew. Energy 2016, 97, 293-305. [CrossRef]

36. Fazelpour, F.; Soltani, N.; Rosen, M.A. Economic analysis of standalone hybrid energy systems for application in Tehran, Iran. Int. J. Hydrogen Energy 2016, 41, 7732-7743. [CrossRef]

37. Banerjee, R. Comparison of options for distributed generation in India. Energy Policy 2006, 34, $101-111$. [CrossRef]

38. Ramli, M.; Hiendro, A.; Twaha, S. Economic analysis of PV/diesel hybrid system with flywheel energy storage. Renew. Energy 2015, 78, 398-405. [CrossRef]

39. Kalinci, Y.; Hepbasli, A.; Dincer, I. Techno-economic analysis of a stand-alone hybrid renewable energy system with hydrogen production and storage options. Int. J. Hydrogen Energy 2015, 40, 7652-7664. [CrossRef]

40. RETScreen@International. Clean Energy Project Analysis (RETScreen Engineering E Cases Textbook), 3rd ed.; Natural Resources Canada: Ottawa, ON, Canada, 2012.

41. Newnan, D.G.; Eschenbach, T.G.; Lavelle, J.P. Engineering Economic Analysis, 9th ed.; Oxford University Press: New York, NY, USA, 2004.

42. Wikipedia. Electricity Sector in India. Available online: https://en.wikipedia.org/wiki/Electricity_sector_in_ India (accessed on 19 April 2020). 
43. Central Electricity Authority. Ministry of Power, Government of India, Executive Summary on Power Sector, October 2019. Available online: http://cea.nic.in/reports/monthly/executivesummary/2019/exe_summary-10. pdf (accessed on 15 April 2020).

44. Central Electricity Authority, Ministry of Power, Government of India, New Delhi, 'Growth of Electricity Sector in India from 1947-2019. Available online: http://www.cea.nic.in/reports/others/planning/pdm/ growth_2019.pdf (accessed on 15 April 2020).

45. Jaganmohan, M. Share of Peak Power Demand Across Maharashtra in India between FY 2016 and FY 2019. Available online: https:/www.statista.com/statistics/1046700/india-maharashtra-peak-power-demand-share/ (accessed on 15 April 2020).

46. Tiewsoh, L.S.; Jirásek, J.; Sivek, M. Electricity Generation in India: Present State, Future Outlook and Policy Implications. Energies 2019, 12, 1361. [CrossRef]

47. Van Ruijven, B.; De Cian, E.; Wing, I.S. Amplification of future energy demand growth due to climate change. Nat. Commun. 2019, 10, 2762. [CrossRef] [PubMed]

48. IEA. Global Energy \& Co2 Status Report 2019. The Latest Trends in Energy and Emissions in 2018, Flagship Report-2019. Available online: https://www.iea.org/reports/global-energy-co2-status-report-2019 (accessed on 15 April 2020).

49. Damm, A.; Köberl, J.; Prettenthaler, F.; Rogler, N.; Töglhofer, C. Impacts of $+2{ }^{\circ} \mathrm{C}$ global warming on electricity demand in Europe. Clim. Serv. 2017, 7, 12-30. [CrossRef]

50. World Energy Outlook 2019-Flagship Report, November 2019. Available online: https://www.iea.org/reports/ world-energy-outlook-2019 (accessed on 15 April 2020).

51. Bhaskar, U. China, India Are Driving Energy Demand Growth. Available online: https://www.livemint.com/ Industry/pERzgaMh5HX5yewWrMCuiO/China-India-are-driving-energy-demand-growth.html (accessed on 15 April 2020).

52. Central Statistics Office, Ministry of Statistics and Programme Implementation, Government of India, New Delhi, Energy Statistics 2019 (Twenty Sixth Issue). Available online: http://www.mospi.gov.in/sites/default/ files/publication_reports/Energy\%20Statistics\%202019-finall.pdf (accessed on 15 April 2019).

53. Seetharaman, G. Why India not Achieve Its 2022 Clean Energy Target. Available online: https://economictimes.indiatimes.com/industry/energy/power/why-india-may-not-achieve-its-2022clean-energy-target/articleshow/71869684.cms?from=mdr (accessed on 15 April 2020).

54. Government of India Ministry of Power Central Electricity Authority. Executive Summary on Power Sector Mar-19. Available online: http://www.cea.nic.in/reports/monthly/renewable/2019/renewable-03.pdf (accessed on 15 April 2020).

55. Soori, H.; Khorasani-Zavareh, D.; Hamid, S.; Khorasani-Zavareh, D. Road traffic injuries measures in the Eastern Mediterranean Region: Findings from the Global Status Report on Road Safety-2015. J. Inj. Violence Res. 2019, 11, 149-158. [CrossRef]

56. Mitavachan, H.; Gokhale, A.; Srinivasan, J. A Case Study of 3MW Scale Grid Connected Solar Photovoltaic Power Plant at Kolar, Karnataka: Performance Assessment \& Recommendations; Report IISc-DCCC 11 RE; Systems Reports, Renewable Energy Divecha Centre for Climate Change; Indian Institute of Science: Bengaluru, Karnataka, India, 2011.

57. Pauschert, D. Study of Equipment Prices in the Power Sector. ESMAP Technical Paper122/09. 2009. Available online: https://esmap.org/sites/default/files/esmap-files/TR122-09_GBL_Study_of_Equipment_Prices_in_ the_Power_Sector.pdf (accessed on 19 June 2019).

58. Mandal, A. A Report on Design Estimation of 1MW Solar PV Plant (Utility Scale). Available online: https://www.academia.edu/3369336/A_Report_on_Design_Estimation_of_1MW_Solar_PV_Plant_ Utility_Scale (accessed on 19 June 2019).

59. Eti, M.; Ogaji, S.; Probert, S. Reducing the cost of preventive maintenance (PM) through adopting a proactive reliability-focused culture. Appl. Energy 2006, 83, 1235-1248. [CrossRef]

60. Diesel Fuel Consumption Chart. Available online: http://www.generatorjoe.net/html/fueluse.html (accessed on 8 May 2019).

61. Central Electricity Regulatory Commission. Explanatory Memorandum for Tariff Norms for Solar Power Projects. July 2009. Available online: http://www.cercind.gov.in/2009/July09/Draft-ExplanatoryMemorandum_Solar-Power-Projects.pdf (accessed on 19 June 2019). 
62. O'Neill, M. MACRS Depreciation. Available online: http://seattlecentral.edu/faculty/moneil/Lectures/macrs. htm (accessed on 8 May 2019).

63. Campbell, H.; Brown, R. Benefit-Cost Analysis: Financial and Economic Appraisal Using Spreadsheets; Cambridge University Press: Cambridge, UK, 2003; p. 360.

64. Trivedi, B. Solar Power Becomes Cheaper Than Diesel in India. Available online: http://www. renewableenergyworld.com/rea/news/article/2011/12/solar-power-becomes-cheaper-than-diesel-in-india (accessed on 23 June 2019).

65. Maharashtra State Electricity Distribution Co. Ltd. Tariff of Non Conventional Energy (NCE)/Renewable Energy Projects for FY 2010-11, Mumbai. 2010. Available online: https://www.mahadiscom.in/consumer/wpcontent/uploads/2018/03/Comm_Cir_122-12Oct.pdf (accessed on 19 June 2019).

66. Maharashtra Electricity Regulatory Commission. Terms and Conditions for Determination of Re-Tariff, Mumbai 2010. Available online: http://www.mercindia.org.in/pdf/Order\%2058\%2042/Final_MERC_RE_ Tariff_Regulation_2010.pdf (accessed on 19 June 2019).

67. Raja, S.V.P.; Sonavani, S.V.L. In the Matter of Determination of Generic Tariff under Regulation 8 of the Maharashtra Electricity Regulatory Commission (Terms and Conditions for Determination of Renewable Energy Tariff) Regulations. 2010. Available online: http://www.mercindia.org.in/pdf/Order\%2058\%2042/ Case_20_of_2010Final_RE_Order.pdf (accessed on 19 June 2019).

68. Obukhov, S.; Ibrahim, A.; Diab, A.A.Z.; Al-Sumaiti, A.S.; Aboelsaud, R. Optimal Performance of Dynamic Particle Swarm Optimization Based Maximum Power Trackers for Stand-Alone PV System Under Partial Shading Conditions. IEEE Access 2020, 8, 20770-20785. [CrossRef]

69. Nguyen, H.T.; Al-Sumaiti, A.S.; Vu, V.P.; Al-Durra, A.; Do, T.D. Optimal Power Tracking of PMSG Based Wind Energy Conversion Systems by Constrained Direct Control with Fast Convergence Rates. Int. J. Electr. Power Energy Syst. 2020, 118, 105807. [CrossRef]

70. Bothra, N. Vinod Kothari \& Company. Carbon Credits-Unravelling Regulatory, Taxation \& Accounting Issues. Available online: http://india-financing.com/Carbon_Credits-Regulatory__Taxation_\&_Accounting\% 20issues.pdf (accessed on 5 June 2013).

71. Shively, G.; Galopin, M. An Overview of Benefit-Cost Analysis. Available online: http://www.agecon.purdue. edu/staff/shively/COURSES/AGEC406/reviews/bca.htm (accessed on 1 January 2015).

72. NPTEL. Lecture 14: Incremental Benefit-Cost Ratio Analysis. Available online: http://nptel.ac.in/courses/ 105103023/22 (accessed on 8 May 2019).

73. Bahaskar, S. Cashing on the Sun: Financial Attractiveness of On-Grid Solar PV and Thermal Projects in India, India. 2010. Available online: https://www.browneandmohan.com/wp-content/uploads/2020/05/Cashing-onthe-Sun.pdf (accessed on 22 May 2020).

74. Vashishtha, S.; Nair, S. Understanding Accelerated Depreciation in Solar Projects. Available online: https://firstgreenconsulting.wordpress.com/2013/05/21/understanding-accelerated-depreciation-insolar-projects/ (accessed on 8 May 2019).

75. Park, C.S. Fundamentals of Engineering Economics: Corporate Taxes (Lecture No.25). 2005. Available online: http://faculty.kfupm.edu.sa/SE/atique/SE307_Engineering_Economics/ (accessed on 8 May 2019).

76. Bales, R. Chapter 9: Project Cash Flow Analysis. Available online: https://eng.ucmerced.edu/people/rbales/ Courses/ENGR155files (accessed on 19 June 2019).

77. Lipsett, M.G. ENGM 401 \& 620-X1: Fundamentals of Engineering Finance, Lecture 28: After Tax Cash Flow. Available online: http://www.ualberta.ca/ \{\}mlipsett/ENGM401_620/ENGM401_620.htm (accessed on 8 May 2019).

78. Mursau, A. Depreciation Accounting (MACRS vs. GAAP Book Depreciation Effect on Taxable Income). Available online: https://www.youtube.com/watch?v=T2mkxmDqGhU (accessed on 8 May 2019).

79. Canadian Wind Energy Association. Small Wind Turbine Purchasing Guide: Off-Grid, Residential, Farm \& Small Business Applications. Available online: https://www.canadianpoultrymag.com/images/stories/small_ wind_purchasing_guide.pdf (accessed on 14 April 2020).

80. Wood, D.; Freere, P. 5-Stand-Alone Wind Energy Systems. Stand-Alone and Hybrid Wind Energy Systems, Technology, Energy Storage and Applications; Kaldellis, J.K., Ed.; Woodhead Publishing Series in Energy. Publisher Woodhead Publishing Limited: Cambridge, UK, 2010. Available online: https://www.sciencedirect. com/science/article/pii/B9781845695279500056 (accessed on 14 April 2020). 
81. Aathmika, Gujarat Solar Policy, Cost of $1 \mathrm{mw}$ Solar Project in Gujarat, Solar Subsidies and Incentives for Off Grid Solar, Steps Involved in Roof-top Solar PV System Designing with Battery Backup. 2012. Available online: http://www.eai.in/club/users/aathmika/blogs/1074/ (accessed on 14 April 2020).

82. Zipp, K. What Are Some Common Types of Solar PV and Storage Installations? Available online: https://www.solarpowerworldonline.com/2015/10/what-are-some-common-types-of-solar-pv-andstorage-installations/ (accessed on 14 April 2020).

83. Leahy, M.J.; Connolly, D.; Buckley, D.N. Chapter 12: Wind Energy Storage Technologies. Available online: https://www.witpress.com/Secure/elibrary/papers/9781845642051/9781845642051021FU1.pdf (accessed on 14 'April 2020).

84. Energy Storage Association. Policies \& Issues, ESA Policy Statements, Positions that Broadly Represent Energy Storage Industry Interests. Available online: https:/energystorage.org/policies-issues/esa-policy-statements/ (accessed on 16 April 2020).

85. Condon, M.; Revesz, R.L.; Unel, B. Managing the Future of Energy Storage, Implications for Greenhouse Gas Emissions. 2018. Available online: https:/policyintegrity.org/files/publications/Managing_the_Future_of_ Energy_Storage.pdf (accessed on 16 April 2020).

(C) 2020 by the authors. Licensee MDPI, Basel, Switzerland. This article is an open access article distributed under the terms and conditions of the Creative Commons Attribution (CC BY) license (http://creativecommons.org/licenses/by/4.0/). 